\title{
2018-2019 Annual Report of Work Carried Out at Memorial Park, City of Houston, Harris County, Texas
}

Michael Quennoz

Follow this and additional works at: https://scholarworks.sfasu.edu/ita

Part of the American Material Culture Commons, Archaeological Anthropology Commons, Environmental Studies Commons, Other American Studies Commons, Other Arts and Humanities Commons, Other History of Art, Architecture, and Archaeology Commons, and the United States History Commons

Tell us how this article helped you.

This Article is brought to you for free and open access by the Center for Regional Heritage Research at SFA ScholarWorks. It has been accepted for inclusion in Index of Texas Archaeology: Open Access Gray Literature from the Lone Star State by an authorized editor of SFA ScholarWorks. For more information, please contact cdsscholarworks@sfasu.edu. 
2018-2019 Annual Report of Work Carried Out at Memorial Park, City of Houston, Harris County, Texas

\section{Creative Commons License}

(c) (1) (9)

This work is licensed under a Creative Commons Attribution-NonCommercial 4.0 International License 


\section{GRAY \& PAPE}

HERITAGE MANAGEMENT
2018-2019 Annual Report of Work Carried Out at Memorial Park,

City of Houston,

Harris County, Texas
TEXAS ANTIQUITIES

PERMIT NUMBER:

8465
PREPARED FUR:

The City of Houston

And

Memorial Park Conservancy

7575 North Picnic Lane

Houston, Texas 77007

PREPARED BY:

Gray \& Pape

110 Avondale Street

Houston, Texas 77006 


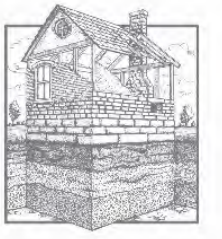

\section{GRAY \&PAPE \\ HERITAGE MANAGEMENT}

Project Nos. 18-72702.001, 19-72701.001, 19-72702.001

2018-2019 Annual Report of Work Carried Out at Memorial Park, City of Houston, Harris County, Texas

Texas Antiquities Permit Number: 8465

Prepared for:

The City of Houston

And

Memorial Park Conservancy

7575 North Picnic Lane

Houston, Texas 77007

(713) 863-8403

Prepared by:

Michael Quennoz

Gray \& Pape, Inc.

110 Avondale Street

Houston, Texas 77006

(713) 541-0473

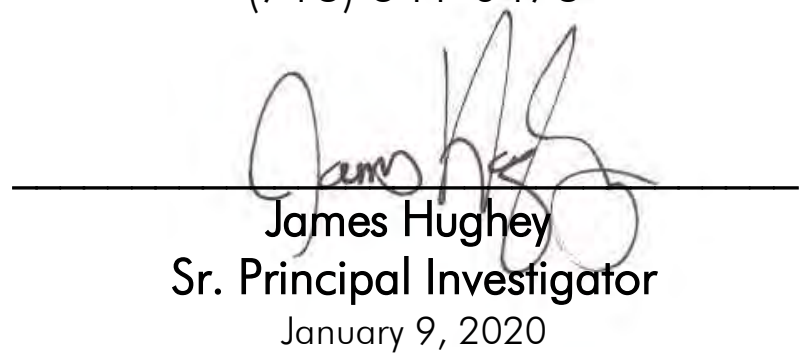




\section{ABSTRACT}

On behalf of the City of Houston and the Memorial Park Conservancy, Gray \& Pape, Inc. conducted intensive pedestrian surveys of three areas totaling 144.4 hectares (357.6 acres) of Memorial Park, City of Houston, Harris County, Texas. Fieldwork was carried out between April 1, 2018 and March 31, 2019, under Texas Antiquities Annual Permit Number 8465. The following report presents the results of site file and background research, survey methods, field results, and conclusions and recommendations for each of these surveys. The goals of the intensive pedestrian surveys were to assist the Memorial Park Conservancy in identifying the presence of cultural resources as they are defined by Section 106 of the National Historic Preservation Act of 1966, as amended (36 CFR 800), and provide management recommendations for identified resources. Survey methods, site identification and delineation, and reporting adhere to standards established by the Archeology Division of the Texas Historical Commission, the Council of Texas Archeologists, and the National Historic Preservation Act of 1966. At this time, the Memorial Park Conservancy plans to conduct standard park maintenance activities including low impact mechanical clearing of the invasive understory, spraying, and new plantings in each of the areas surveyed.

Gray \& Pape, Inc. focused particular attention on the State Antiquities Landmark-designated (\#8200003264) Camp Logan archaeological site (41HR614) that encompasses large portions of Memorial Park. As a result of survey findings, the boundary for 41 HR61 4 has been expanded to include the entirety of the former Camp Logan footprint as preserved within the boundaries of Memorial Park. The boundary of the previously recorded prehistoric site $41 \mathrm{HR} 1217$ was also extended. Four new prehistoric sites (41HR1226, 41HR1227, 41HR1229, 41HR1230) and one new multicomponent site (41HR1228) were also recorded.

The 12.4-hectare (30.6-acre) Sports Complex survey resulted in the identification of five historic features considered part of 41HR614: the partial remains of a Camp Logan era road, segments of two Camp Logan era ditches, a Camp Logan concrete grease trap, and a concrete signpost from the 1940s. Gray \& Pape recommends that the grease trap and signpost be avoided by Memorial Park Conservancy planned activities. The remaining features will not be impacted by current planned Memorial Park Conservancy activities. Based on the results of this survey, and with these protective measures in place, Gray \& Pape recommends that the no further cultural resources work be required in the remaining portions of the Sports Complex project area and that the project be cleared to proceed as currently planned.

The 76-hectare (189-acre) Bayou Wilds - East survey resulted in the identification of four new prehistoric sites (41HR1226, 41HR1227, 41 HR1229, 41 HR1230) and one new multicomponent site (41HR1228). The boundaries of the prehistoric site $41 \mathrm{HR} 1217$ and the historic site $41 \mathrm{HR} 614$ were extended A total of 14 new features were identified as associated with $41 \mathrm{HR} 614$, as well as two historic-age structures. Gray \& Pape, Inc. recommends avoidance of the identified sites, features, and historic age structures. Based on the results of this survey, and with these protective measures in place, Gray \& Pape, Inc. recommends no further cultural resources work be required in the remaining portion of the Bayou Wilds - East project area and that the project be cleared to proceed as planned.

The 56-hectare (138-acre) Northwest Trails - North survey resulted in the identification of four historicage structures, nearly identical footbridges constructed of irregular blocks and mortar that are part of the park's active trail network; as well as a historical isolate. Based on the results of this survey, and with these protective measures in place, Gray \& Pape, Inc. recommends that the no further cultural resources 
work be required in the remaining portions of the Northwest Trails - North project area and that the project be cleared to proceed as currently planned.

As part of the Unanticipated Finds Plan developed by Gray \& Pape, Inc. and the Memorial Park Conservancy, Gray \& Pape, Inc. archaeologists identified and recorded nine cultural features (seven manholes, one grease trap, one segment of vitrified clay pipe) uncovered by activities undertaken by the Memorial Park Conservancy and their contractors. In each case ongoing work in the area of the newly encountered feature was halted until the feature was fully documented by a Gray \& Pape, Inc. archaeologist, and potential impacts were coordinated between Gray \& Pape, Inc., the Memorial Park Conservancy, and the Texas Historical Commission. Gray \& Pape, Inc. also coordinated with the Texas Historical Commission on two occasions in relation to Memorial Park Conservancy projects for which no fieldwork was required.

As a project permitted through the Texas Historical Commission, Gray \& Pape, Inc. submitted project records to the Center of Archaeological Studies at Texas State University in San Marcos, Texas. 


\section{TABLE OF CONTENTS}

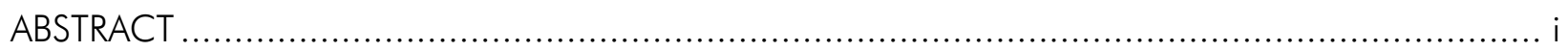

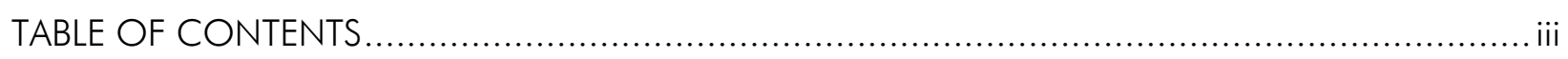

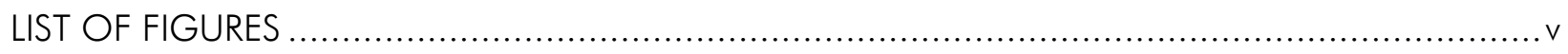

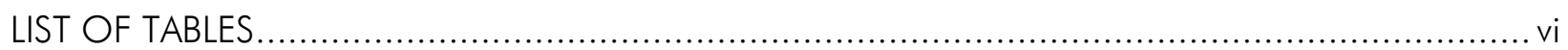

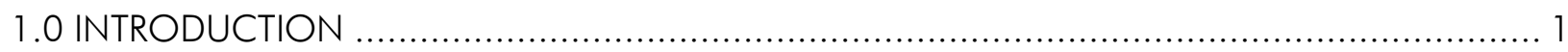

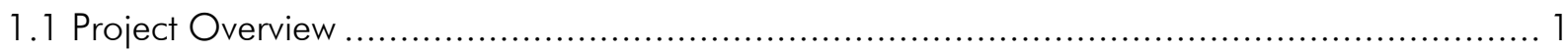

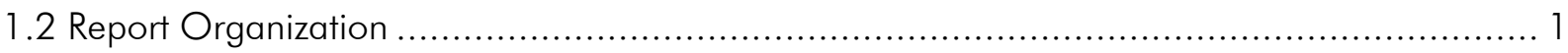

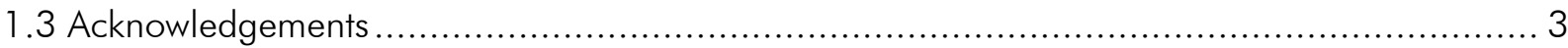

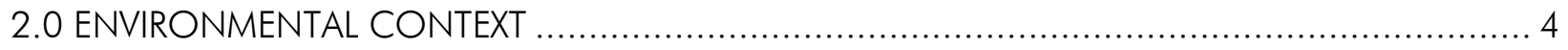

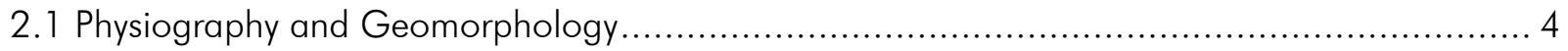

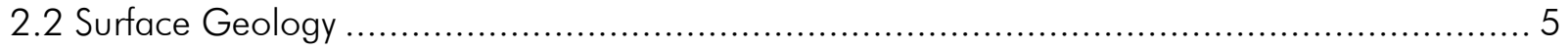

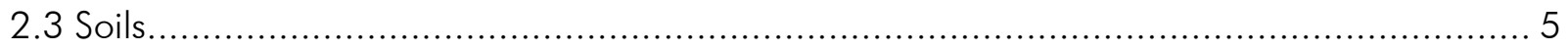

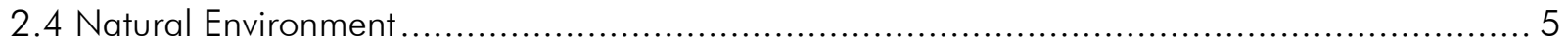

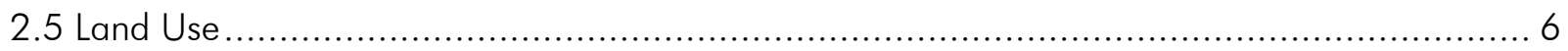

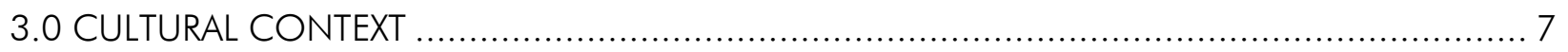

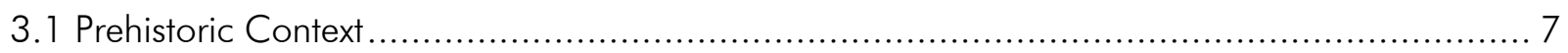

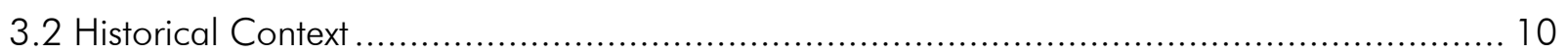

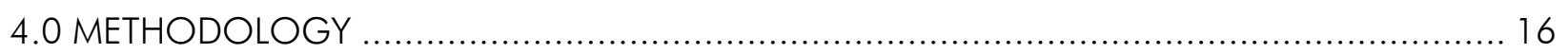

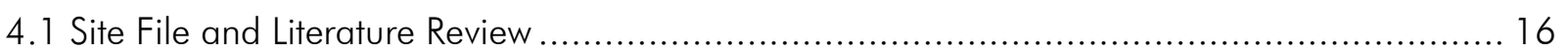

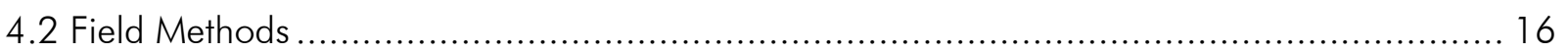

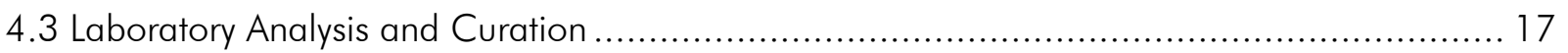

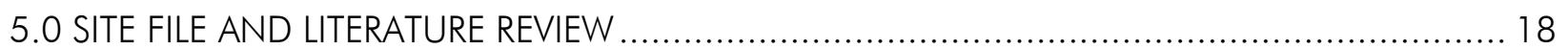

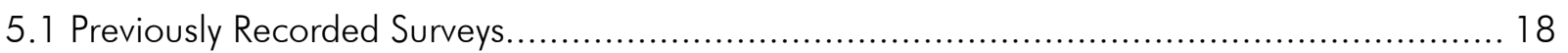

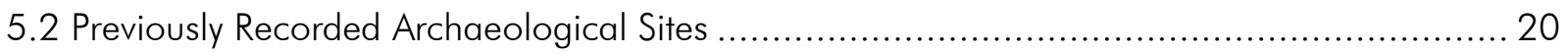

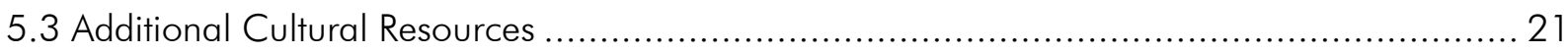

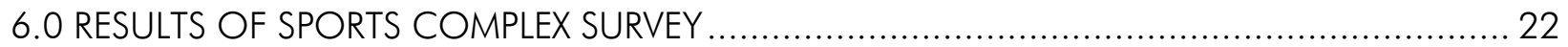

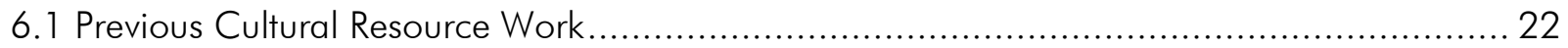

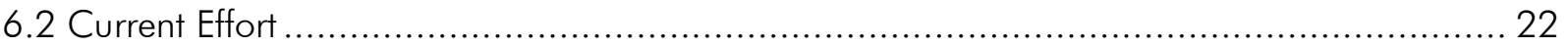

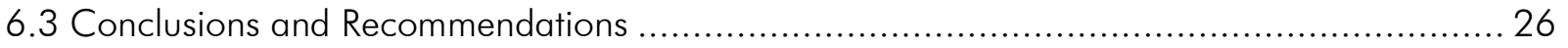


7.0 RESULTS OF BAYOU WILDS - EAST SURVEY ................................................... 27

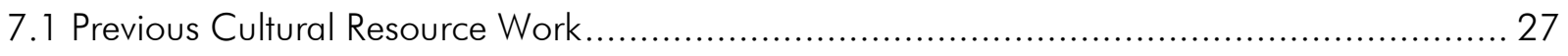

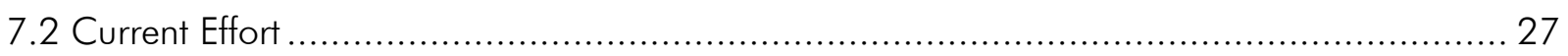

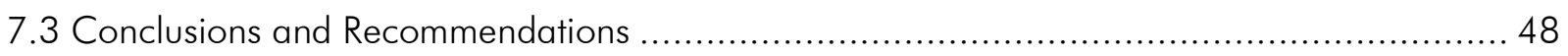

8.0 RESULTS OF NORTHWEST TRAILS - NORTH SURVEY ............................................ 49

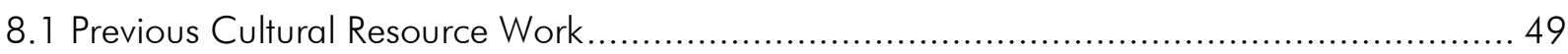

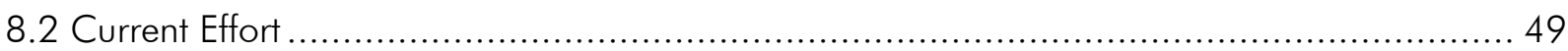

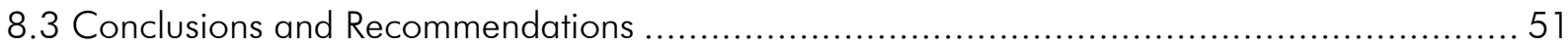

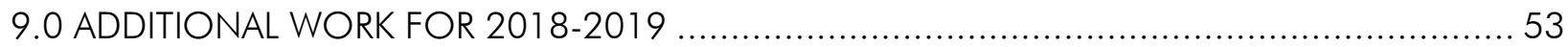

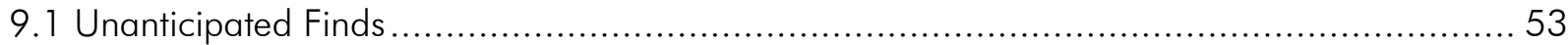

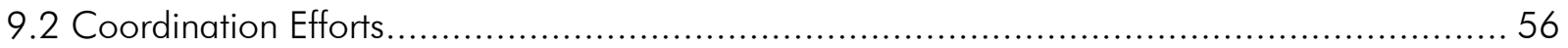

10.0 CONCLUSION AND RECOMMENDATIONS .................................................... 57

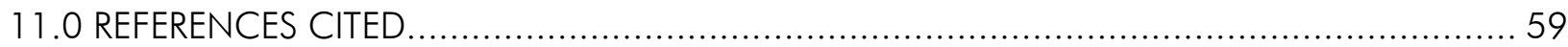

APPENDIX A: HISTORIC CAMP LOGAN MAPS

APPENDIX B: TABLE OF RECORDED FEATURES

APPENDIX C: UNANTIPATED FINDS PLAN

APPENDIX D: COORDINATION LETTERS 


\section{LIST OF FIGURES}

Figure 1 1. Project area locations in Harris County, Texas....................................................... 2

Figure 2-1. Drainage flowing into Buffalo Bayou. View is to the south. ....................................... 4

Figure 2-2. Example of a large drainage gulley within Memorial Park. View is to the south............... 5

Figure 2-3. Developed picnic area in Memorial Park. View is to the southeast................................ 6

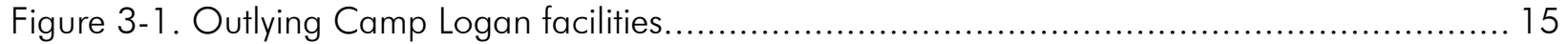

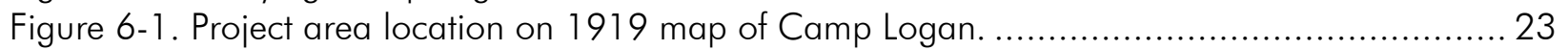

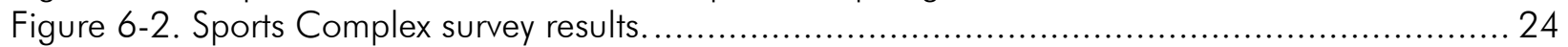

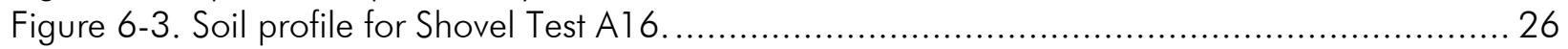

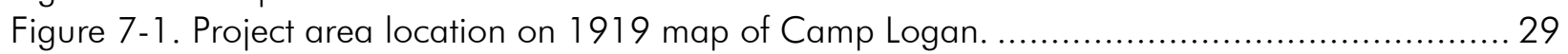

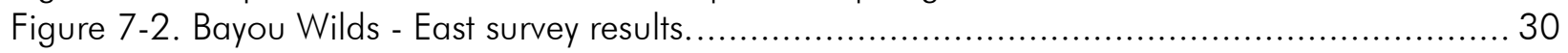

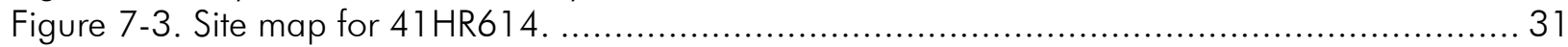

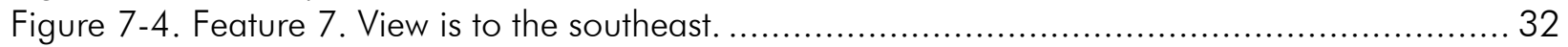

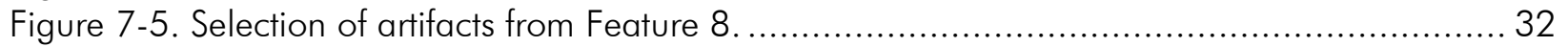

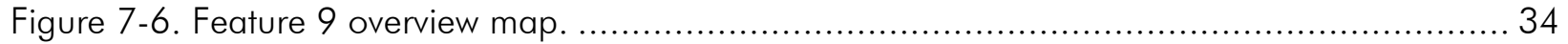

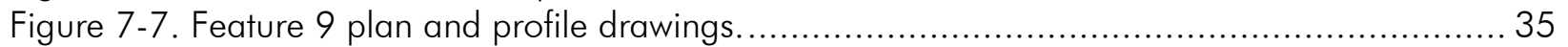

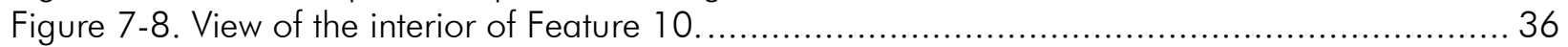

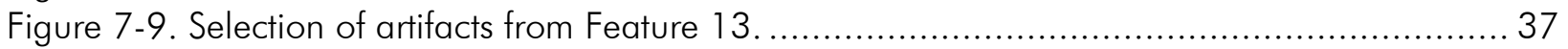

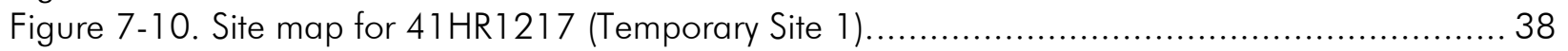

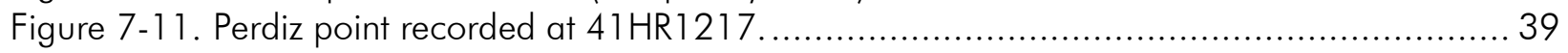

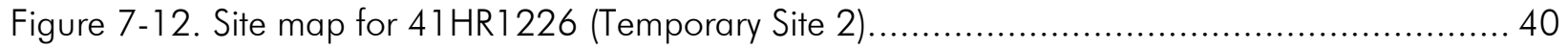

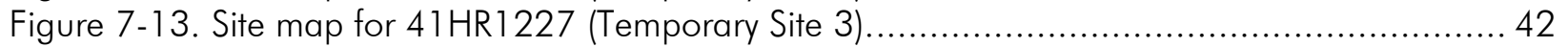

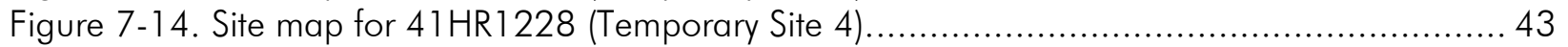

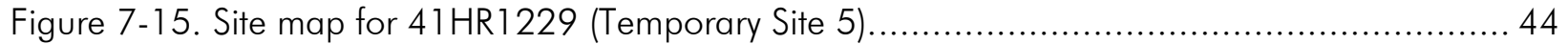

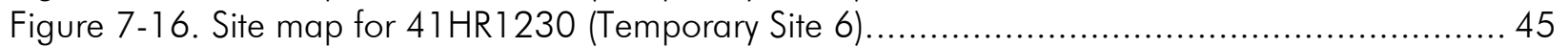

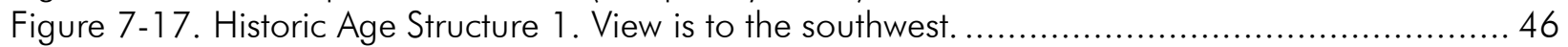

Figure 7-18. Detail of mortar roof bracket on Historic Age Structure 1 ................................... 46

Figure 7-19. Typical example of concrete rubble deposited in erosional gully. View is to the east.... 47

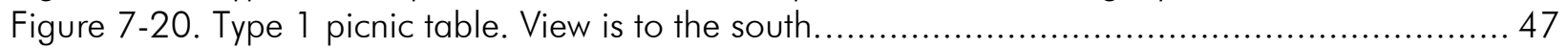

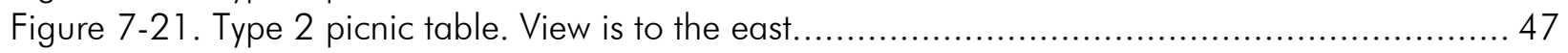

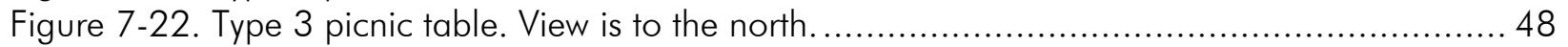

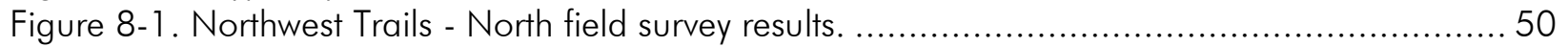

Figure 8-2. Historic Age Structure 4. View is to the southeast. .................................................. 51

Figure 8-3. Soil profiles for Northwest Trails - North. ........................................................ 52

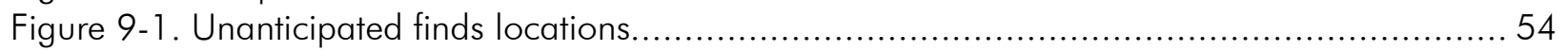

Figure 9-2. Feature 5, a partially submerged manhole. View is to the southeast. .........................55

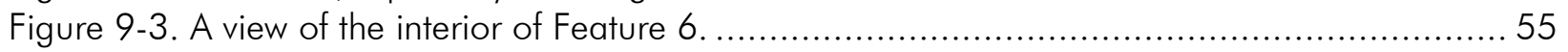

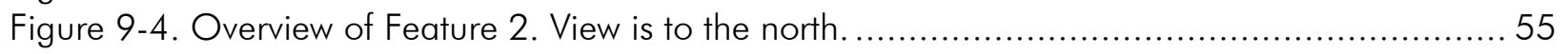

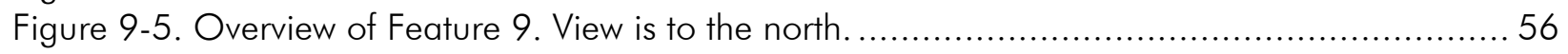

Figure 9-6. Feature 12 in the Land Bridge area. View is to the southeast................................... 56

Figure 9-7. Overview of Feature 6 in the Sports Complex area. View is to the east. ....................... 56 


\section{LIST OF TABLES}

Table 1-1. 2018-2019 Projects Conducted Under Annual Texas Antiquities Permit 8465............... 1 Table 5-1. Previously Recorded Surveys within 1.6 Kilometers (1 Mile) of Memorial Park, Harris County, Texas.

Table 5-2. Previously Recorded Archaeological Sites within 1.6 Kilometers (1 Mile) of Memorial Park,

Harris County, Texas. .......................................................................................... 21 


\subsection{INTRODUCTION}

On behalf of the City of Houston and the Memorial Park Conservancy (MPC), Gray \& Pape, Inc. (Gray \& Pape) conducted intensive pedestrian surveys of three areas totaling 144.4 hectares (357.6 acres) of Memorial Park, City of Houston, Harris County, Texas (Table 1-1). Fieldwork was carried out between April 1, 2018 and March 31, 2019. The following report presents the results of site file and background research, survey methods, field results, and conclusions and recommendations for each of these surveys.

\subsection{Project Overview}

Memorial Park is located on the Houston Heights, TX. United States Geological Survey (USGS) 7.5-minute topographic quadrangle map in the City of Houston, Harris County, Texas (USGS 1998; Figure 1-1). The goals of the intensive pedestrian surveys were to assist the MPC in identifying the presence of cultural resources as they are defined by Section 106 of the National Historic Preservation Act (NHPA) of 1966, as amended (36 CFR 800), and provide management recommendations for identified resources. Gray \& Pape focused particular attention on the State Antiquities Landmarkdesignated (\#8200003264) Camp Logan archaeological site (41HR614) that encompasses large portions of Memorial Park. Survey methods, site identification and delineation, and reporting adhere to standards established by the Archeology Division of the
Texas Historical Commission (THC), the Council of Texas Archeologists, and the NHPA of 1966.

As Memorial Park is a property of the City of Houston, a political subdivision of the state of Texas, the project requires the completion of an archaeological survey and due consideration of identified archaeological resources prior to project commencement, per the Texas State Antiquities Code (1977). Fieldwork and reporting for the survey were conducted under Texas Antiquities Annual Permit Number 8465, issued to Gray \& Pape by the THC. Gray \& Pape has previously conducted two surveys in Memorial Park under Texas Antiquities Permit Numbers 7574 (Quennoz and Valenti 2017) and 7686 (Quennoz and Valenti 2016). Multiple surveys were carried out in 2017-2018 under Texas Antiquities Annual Permit No 7978 (Quennoz 2018).

\subsection{Report Organization}

This report is organized into 11 numbered chapters and 4 lettered appendices. Chapter 1.0 provides an overview of the project. Chapter 2.0 presents an overview of the environmental setting and geomorphology. Chapter 3.0 presents a discussion of the cultural context and history associated with the project area. Chapter 4.0 presents the research design and methods developed for this investigation.

Table 1-1. 2018-2019 Projects Conducted Under Annual Texas Antiquities Permit 8465.

\begin{tabular}{|c|c|c|c|c|}
\hline Gray \& Pape Project No. & Project Name & Size (hectares/acres) & New Sites & Revisited Sites \\
\hline $18-72702.001$ & Sports Complex & $12.4 / 30.6$ & NA & $41 \mathrm{HR} 614$ \\
\hline & & & $41 \mathrm{HR} 1226$ & \\
$19-72701.001$ & Bayou Wilds - East & $76.3 / 189.0$ & $41 \mathrm{HR} 1227$ & $41 \mathrm{HR} 614$ \\
& & & $41 \mathrm{HR} 12229$ & $41 \mathrm{HR} 1217$ \\
& & & $41 \mathrm{HR} 1230$ & \\
\hline $19-72702.001$ & Northwest Trails - North & $55.7 / 138.0$ & NA & NA \\
\hline
\end{tabular}




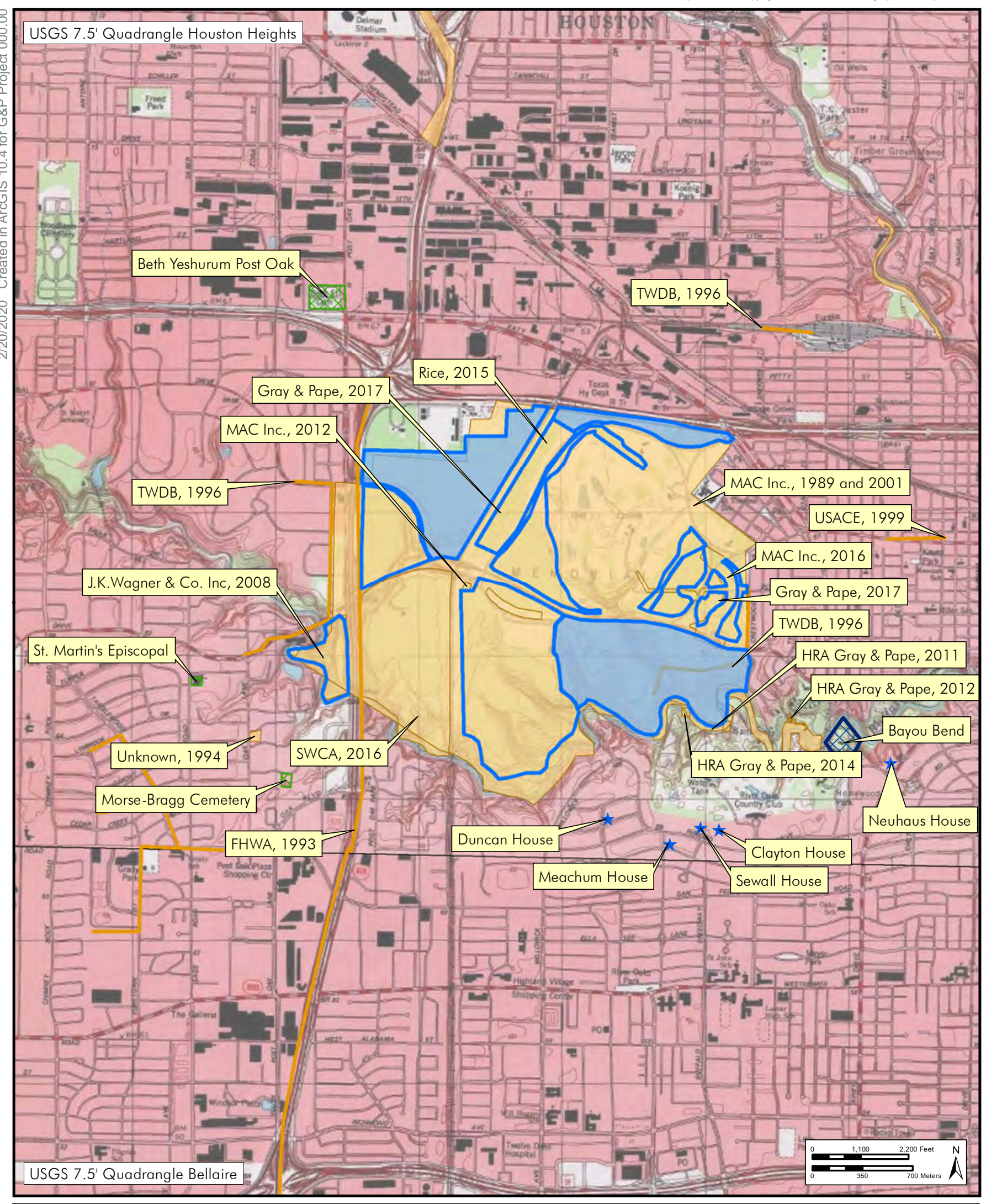

Figure 1-1

Project Area Map in Harris County, Texas

GRAY $\&$ PAPE

HERITAGE MANAGEMENT

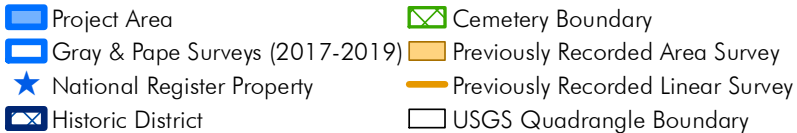

Historic District

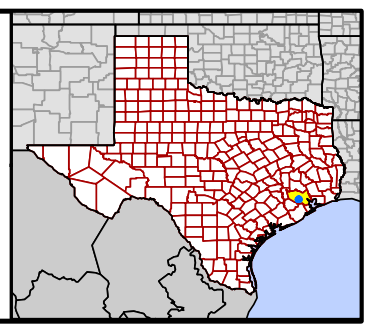


The results of the site file and literature review are presented in Chapter 5.0. Chapters 6.0 through 9.0 presents the investigation summaries and provides recommendations based on the results of field survey for each of the individual projects carried out under the annual permit. Chapter 10.0 provides a closing summary for all survey work carried out under the annual permit. A list of literary references cited in the body of the report is provided in Chapter 11.0. Appendix A presents georeferenced historic Camp Logan maps with the project areas superimposed. Appendix B provides a table of all features identified during the course of the annual permit, as well as features identified by Gray \& Pape during previous surveys within Memorial Park (Quennoz and Valenti 2016, 2017, Quennoz 2018). Appendix $C$ presents an Unanticipated
Finds plan and Appendix D includes coordination efforts with the THC that did not require fieldwork efforts.

\subsection{Acknowledgements}

Fieldwork was conducted under the direction of Archaeologist Michael Quennoz with assistance from Principal Investigator Tony Scott, Archaeologists Jacob Hilton and Morgan Wampler, and Archaeological Technicians Hilda Torres and Amanda Kleopfer. Jim Hughey served as Principal Investigator and Project Manager. Fieldwork required approximately 330-person hours to complete. Michael Quennoz prepared the report. Duncan Hughey prepared the report graphics. The report was edited and produced by Jessica Bludau. 


\subsection{ENVIRONMENTAL CONTEXT}

\subsection{Physiography and Geomorphology}

Harris County sits largely within the Texas Coastal Plain, a part of the larger Gulf Coastal Plain, a low, level to gently sloping region extending from Florida to Mexico. The Texas Coastal Plain reaches as far north as the Ouachita uplift in Oklahoma, and as far west as the Balcones escarpment in central Texas. The basic geomorphological characteristics of the Texas coast and associated inland areas, which includes Harris County, resulted from depositional conditions influenced by the joint action of sea level changes from glacial advance in the northern portions of the continent, and subsequent down cutting and variations in the sediment load capacity of the region's rivers. Locally, Harris County is underlain by relatively recent sedimentary rocks and unconsolidated sediments ranging in age from the Miocene to Holocene (Abbott 2001; Van Siclen 1991).

Topographic relief is the result of down cutting of sediments from fluvial action associated with the many rivers, bayous, and creeks within and around Harris County. Major drainages include the Brazos River to the west, the Colorado River to the north, and San Jacinto River to the east. Creeks and bayous that border or dissect Harris County include Spring and Cypress creeks to the north, Cedar Bayou to the east, Buffalo Bayou in central Harris County, and Clear Creek, Brays Bayou, and Keegans Bayou to the south (Abbott 2001).

Within Memorial Park, the most consequential topographic feature is Buffalo Bayou which flows along the park's western and southern boundaries (Figure 2-1). Buffalo Bayou is spring-fed and originates in Waller County, flowing west to east, through Houston, and draining into the San Jacinto River. The stream channel primarily cuts into Beaumont clay of
Pleistocene age. Along the banks these clays are overlain with a combination of ancient and recent alluvium (Chowdhury and Turco 2006).

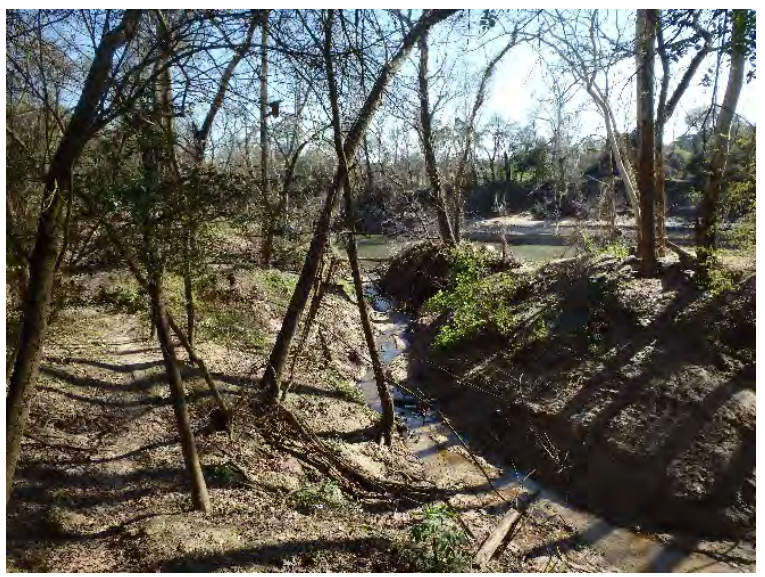

Figure 2-1. Drainage flowing into Buffalo Bayou. View is to the south.

The relatively level areas in the northern and central portions of the park are interspersed with relatively small, shallow depressions. These depressions frequently flood and hold water during and after heavy rains. In some areas, ponding and flooding have been exacerbated by collecting runoff from parking lots, ball fields, and trails. These areas can be saturated nearly year-round. The level landscape of the northern portions of the park gives way to an increasingly dissected landscape in the park's southern areas. Here, numerous ravines drain into Buffalo Bayou. The deepest and largest of these drainages can be a much as 10 meters (30 feet) deep and 80 meters (260 feet) across (Figure 2-2). The drainages have formed numerous interfluve ridges across the portions of the park bordering Buffalo Bayou. Comparison of historical topographic maps between 1915 and 2013 show that these ridges have been eroding and narrowing as the drainages widen (Nationwide Environmental Title Research, LLC [NETR] Online 2019). 


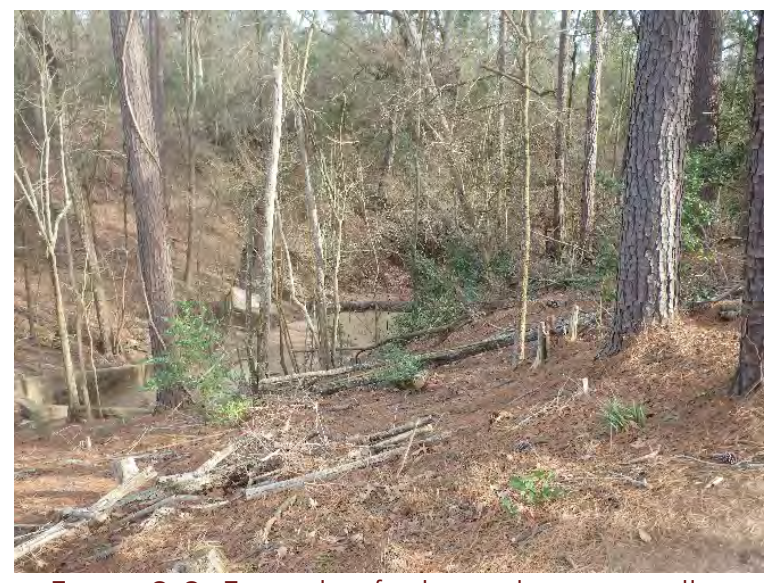

Figure 2-2. Example of a large drainage gulley within Memorial Park. View is to the south.

\subsection{Surface Geology}

Although older geologic units have been identified in the region (Abbott 2001; Barnes 1992; Van Siclen 1991), units relevant to the study of long-term human occupation in modern-day Harris County include the Beaumont Formation, generally believed to predate human occupation in the region, and the so-called "Deweyville" terraces, positioned stratigraphically between the Beaumont and Recent deposits. These terraces date to between one hundred thousand to four thousand years ago and are characterized as consisting "of up to three inset fluvial terraces... (distinguished by the presence of) ...large looping meander scars..." indicative of watercourses capable of fluvial action and discharge markedly greater than that seen today (Abbott 2001;16). Overlaying these deposits may be relatively thick or thin Holocene deposits, laid down in the Harris County area by alluvial or eolian factors, or potentially, marshy environments.

Memorial Park is underlain by two subdivisions of the Beaumont Formation. The majority consists of Beaumont Formation, areas predominantly clay. An area of the park, largely located underneath the Memorial Park Golf Course, is mapped as Beaumont Formation, areas predominantly sand (Barnes 1992).

\subsection{Soils}

A general soil map for Memorial Park shows the Katy-Aris association to the north and west and Aldine-Ozan association to the south and east. The Katy-Aris association consists of nearly level loamy soils on prairies while the Aldine-Ozan association are nearly level loamy soils more typical of a forested environment (Wheeler 1976).

\subsection{Natural Environment}

\subsubsection{Flora and Fauna}

Present-day Harris County is located near the western edge of the Austroriparian biotic province and is situated in the Upland Prairies and Woods subregion of the Gulf Coast Prairies and Marshes Region (Abbott 2001). Evidence from pollen analysis in Central Texas suggests that, at least during the Late Pleistocene, the area may have been populated by vegetative species that were tolerant of a cold weather environment. Climactic fluctuation during the Holocene would eventually result in a gradual trend towards warmer weather, similar to that seen today (Abbott 2001).

Late Pleistocene flora may have included populations of spruce, poplar, maple, and pine (Holloway 1997) in an oak woodland environment that would eventually transition to an oak savanna in the late Holocene (Abbott 2001). Fauna during this time would include currently present species such as white-tailed deer and various smaller game, as well as bison, and, in localized areas, pronghorn sheep and the American alligator (Abbott 2001).

Outside of manicured areas such as the golf course and ballfields, the modern vegetative community within Memorial Park consists of a tree canopy of pine and oaks. However, Hurricane lke in 2008, and an extended drought beginning in 2010, greatly thinned the overstory allowing the understory to dominate. This can include thick stands of yaupon and briar (Suzanne Turner Associates 2015). 
The modern faunal community includes mammals such as rats, armadillo, opossum, skunk, and coyote, numerous bird species, and reptiles including frogs, toads, skinks, alligator snapping turtles, and anoles (SWCA Environmental Consultants 2017). Black bear, although now absent, were present into the early twentieth century as evidence by one that wandered into Camp Logan and became the unofficial mascot of the soldiers in training (Aulbach et al. 2014:91).

\subsubsection{Climate}

Harris County's proximity to the Gulf of Mexico tends to influence the temperature, rainfall, and relative humidity of the region. Winds usually trend from the southeast or east, except during winter months when high-pressure systems can bring in polar air from the north. Average temperatures in the summer can reach well into the 90s degrees Fahrenheit (30s degrees Celsius) and are often accompanied by equally high humidity. Although winter temperatures can reach into the low 30s degrees Fahrenheit (0 degrees Celsius), below freezing temperatures usually occur on only a few days out of every year and are typically restricted to the early morning hours. Rainfall is evenly distributed throughout the year, with an average monthly distribution ranging from between 43 centimeters (17 inches) to trace amounts; rainfall comes primarily from thunderstorms, which tend to be heavy but of short duration (Wheeler 1976:2).

\subsection{Land Use}

Memorial Park is a public park owned by the City of Houston that presently encloses approximately 590 hectares (1,460 acres). The park is situated along the north bank of Buffalo Bayou, with its northern and western edges defined by Interstate 10 and Interstate 610, respectively. Along its eastern boundary, Memorial Park is bordered by mixed light residential and commercial neighborhoods, most notably the Crestwood and Rice Military neighborhoods. The park is bisected by Memorial Drive and this central portion of the park is the most highly developed, including the Memorial Park Golf Course, baseball and softball fields, tennis courts, park buildings, picnic areas, and parking lots (Figure 2-3). The western and southern areas of the park are less developed and can be accessed by an extensive trail system used by pedestrians and bicyclists.

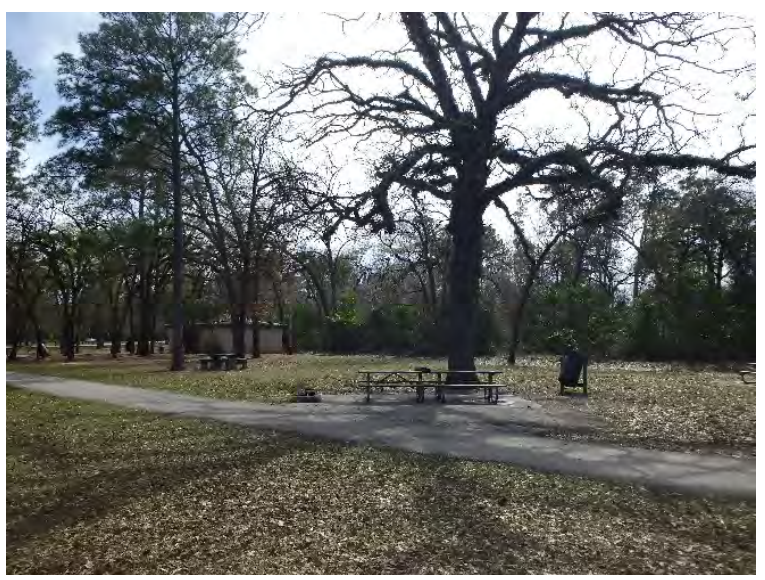

Figure 2-3. Developed picnic area in Memorial Park. View is to the southeast. 


\subsection{CULTURAL CONTEXT}

\subsection{Prehistoric Context}

Traditionally, Southeast Texas has been viewed as a buffer zone between cultural regions in prehistoric times. Patterson (1995) describes the archaeological record in this area as being an interface between the Southern Plains and the Southeast Woodlands. Along similar lines, both Shafer (1975) and Aten (1984) have categorized the Post-Archaic archaeological record of this region as Woodland. This categorization is not meant to literally invoke the exact cultural patterns and chronology of the Woodlands culture found to the east. Aten (1984:74) summarizes his concept by saying, "it loosely connotes activities by populations on a geographic as well as a cultural periphery of the southeastern Woodlands."

Dee Ann Story (1990) has suggested that the culture of Southeast Texas is distinctive enough to merit a separate designation by the Late Prehistoric. The Mossy Grove cultural tradition is a heuristic concept based on technological similarities shared by groups in this region. The primary marker of this technological tradition is the plain, sandy-paste Goose Creek pottery that is found in this region from the Early Ceramic through Early Historic periods.

Ethnic affiliations for the region are not entirely clear. Aten (1983) has defined the Brazos Delta-West Bay, Galveston Bay, and Sabine Lake archaeological areas and suggests that they may correlate with the Historic territories of the Coco, Akokisa, and Atakapa groups, respectively. Similarly, historic reconstructions of the inland subregion suggest a number of possible group affiliations (Story 1990). The historic economic inland/coastal cycle of the Akokisa, which stretched from Galveston Bay to the San Jacinto River basin, may mean that archaeological materials in the Lake Conroe area are affiliated with this group. Alternately, these remains may be associated with the Bidais who occupied territory immediately to the north of the Akokisa groups. At this point in time, it is not possible to identify the cultural affiliation of the groups that inhabited the inland subregion. In part, this is a function of the dynamic nature of this region in which several cultural traditions met and diffused.

The Southeast Texas region is divided into inland and coastal margin subregions, which have archaeologically distinctive subsistence patterns, settlement patterns, and artifact types. Archaeological and historical evidence suggests that some groups exploited inland resources year-round, while other groups spent parts of the year both inland and on the coast.

Based on aspects of material culture, researchers have identified six archaeological time periods associated with Native Americans in the Southeast Texas region; in general, these include the Paleoindian, Archaic (with Early, Middle, and Late subdivisions), Ceramic, Late Prehistoric, Protohistoric, and Historic Indian. Archaeologists within the region agree on the general framework of cultural time periods, while disagreeing on the temporal boundaries of these periods. Despite these differences, the chronologies developed by researchers are based primarily on changes in projectile point technologies within the region and the introduction of pottery. It is generally recognized that a broad-based hunting and gathering lifestyle was utilized throughout all time periods. For the purpose of this document, the temporal boundaries of prehistoric periods will be primarily based on Story (1990) and Aten (1983) and this information is merged with the archaeological data here to give a complete picture of life on the Upper Texas Coast.

\subsubsection{Paleoindian Period}

Along the Upper Texas Coast, the Paleoindian period (termed the Early Cultures by Story) begins around 12,000 Before Present (B.P.) and 
ends near 9,000 to 8,000 B.P. (Aten 1983; Story 1990). Evidence is sparse for Paleoindian habitation, and much of what is known about the period in the area comes from a compilation of materials gathered from the state of Texas and North America. At the close of the Pleistocene, large game hunters crossed the Bering Strait, and within a few millennia had penetrated South America (Culberson 1993; Newcomb 1961). The Paleoindian people traveled in small bands (Culberson 1993) and were mega-fauna hunter-gatherers with the bulk of their meat protein derived from mammoths, mastodons, giant bison, and giant sloths. These groups carried with them an easily recognizable stone tool material culture, though admittedly, little is known about their wooden or bone tools and clothing types. The later Folsom Culture developed a very efficient toolkit that was apparently designed to be portable leading to theories that these people were following buffalo herds across the plains. However, the widespread use of Folsom technology suggests that the technology spread beyond the area for which it was initially designed. Isolated Paleoindian artifacts found across southeastern Texas include Clovis, Angostura, Scottsbluff, Meserve, Plainview, and Golondrina point types (Aten 1983).

The Transitional Archaic period begins about 9,000 B.P. and ends around 7,500 B.P. (Aten 1983; Story 1990). This stage is also poorly represented in the archaeological work in the area; however, recent data recovery efforts at the Dimond Knoll Site (41HR796) have contributed to the knowledge of the Paleoindian and early Archaic occupation in the area of Harris County in particular (Barrett and Weinstein 2013). Isolated finds of Bell/Calf Creek, Early-Side Notched, and Early Expanding Stemmed dart points are also attributed to this time period.

\subsubsection{Archaic Period}

With the retreat of the glaciers (the Hypsithermal period), the mega-fauna upon which the Paleoindian peoples depended gradually became extinct. This shift in food supply is seen as the pivotal transition point between the Paleo and Archaic periods (Biesaart et al. 1985; Culberson 1993; Newcomb 1961). Though dates often disagree (ranging from 8,000 B.C. marking the beginning of the Early Archaic [Culberson 1993], to Aten [1984] stating that the transition from Late Archaic to Late Prehistoric-Woodland began around A.D. 100), there are three progressive stages recognizable during the Archaic period: the Early, Middle, and Late.

Much of what is known about the Early Archaic peoples indicates that they were small, isolated bands of hunter-gatherers that remained in relatively restricted regions (Aten 1984). With the loss of the mega-fauna as a food source, the Early Archaic peoples adopted the hunting of smaller game such as bison and deer and increased their reliance on foraging (Culberson 1993). The material record fits the transitional makeup of this period because there was a dramatic shift from the large spear points of the Paleoindian period to a reliance on smaller dart-type points. Diagnostic designs for this period are Dalton, San Patrice, Angostura, Golondrina, Merserve, Scottsbluff, Wells, Hoxie, Gower, Uvalde, Martindale, Bell, Andice, Baird, and Taylor (Turner and Hester 1993). These points are much more crudely made than their Paleo precursors but remain designed for use on a spear shaft.

The Middle Archaic period saw the largest growth in technology and in the number of stone tools utilized. Specialized tools appeared for the milling of wild plant foodstuffs (Culberson 1993) along with a large assortment of tools for food preparation and procurement. Gravers, scrapers, axes and choppers, knives, drills, and polished stone tools, also known as ground stone tools, began to appear in large quantities (Newcomb 1961). Diagnostic points such as Gary, Kent, Palmillas, Nolan, Travis, Belvedere, Pedernales, Marshall, Williams, and Lange dominate the spectrum of dart points from the Middle Archaic period (Turner and Hester 1993; see also the Edwards Plateau 
Aspect [Newcomb 1961]). The advent of the atlat also seems to be placed within this period (Culberson 1993).

The Late Archaic period saw a dramatic increase in the population densities of Native American groups. Human habitation of areas rich in diverse flora and fauna intensified, as did the variety of materials and artifacts (Culberson 1993; Aten 1984). Late Archaic peoples began relying heavily on foraging tubers, berries, and nuts and hunting small game such as deer, rabbits, and raccoons, as well as fish and shellfish, and birds. Groups became socially more complex than earlier periods and the result was an increasing intercommunication with neighboring groups. Culberson (1993:55) states that a "Lapidary Industry" developed in which stone artifacts were made from exotic materials (jasper, hematite, quartz, shale, slate, etc.) acquired from sources great distances away. These materials were fashioned into an increasingly complex array of household goods such as celts, plummets, banner stones, mortars and pestles, and pendants; also during this period, there is an increase in the occurrence of sandstone bowls (Culberson 1993). Diagnostic points of this period are difficult to distinguish from those of the Middle Archaic. Gary and Kent points remain prevalent in southeast Texas, while other points such as Marcos, Montell, San Gabriel, Mahomet, Fairland, and Castroville also appear at times (Turner and Hester 1993).

The Archaic period in southeast Texas ends with the adoption of ceramic technology at the beginning of the Ceramic period. Patterson (1995) places the beginning of the Early Ceramic period on the Texas coast from 100600 A.D. Aten (1983) placed the appearance of pottery in the Galveston Bay area approximately 100 A.D. The ceramic chronology of the inland areas parallels that of the coast; however, it does not manifest until several centuries later. The inland areas generally lack the earliest ceramic types present in the coastal region as well as some of the later ceramic types (Aten 1983; Story 1990). As a result of trade networks or stylistic/manufacturing influences, it appears that ceramic traits moved from the coast to the inland areas and from the east to the west (Aten 1983).

\subsubsection{Late Prehistoric}

The transitional period between Late Archaic and Woodland-Late Prehistoric is a period marked by an intensification of group dynamics across Texas. The advent of the bow and arrow is believed by most (Aten 1984; Culberson 1993; Newcomb 1961) to be from this period, though some may place it later. Most importantly for archaeological investigations, the first signs of pottery begin to emerge at sites from this period (Aten 1983). Although the amount and variety of pottery intensifies during the Late Prehistoric, it is an excellent way of determining the terminus post quem of a site. Fishing, bison hunting, and the collection of wild flora intensifies beyond the level of the Late Archaic period during this stage, but there is no sufficient data to demonstrate the initial advent of a sedentary agricultural lifeway. The diagnostic points of this period are Catahoula, Friley, Alba, and Bonham (Turner and Hester 1993).

The Late Prehistoric (also known as Woodland and Ceramic periods) continue from the end of the Archaic period to the Historic period ushered in by the Spanish Missions and AngloAmerican settlers. During this period, there is a shift to the almost total use of arrow points such as Perdiz and, later, Scallorn, and a wide variety of ceramic types. According to Aten (1984), there are nearly 18 different types of pottery from this period currently identified for the east Texas Coast alone based on temper, paste, and design.

Goose Creek and other sandy paste pottery types are often recovered from Ceramic period and Late Prehistoric sites throughout southeast Texas. Goose Creek appears in Aten's coastal chronology to greater or lesser extents in nearly every period, particularly Mayes Island, Turtle Bay, Round Lake, and the later Orcoquisac 
periods. Because of the predominance of sandy paste pottery across the region, Story (1990) has suggested the Mossy Grove Tradition as an encompassing cultural tradition for the area. Other ceramic forms that occur in the region include grog-tempered, stamped, and bonetempered pottery (Patterson 1996).

\subsubsection{Protohistoric Period to the Post- Contact}

It is during this period that peoples known today as the Caddo, Attakapans, and Bidai, to name a few, are identifiable both culturally and materially. This is mostly due to the historical sources of the seventeenth through the nineteenth centuries that aid in the reconstruction of the past cultures in the area. In order to better understand the complexity of the region's cultures, researchers turn to historical sources to get an understanding of the peoples who first occupied the southeast Texas. Hernando De Soto encountered the Native Americans of the region during his expedition in 1542 (Hudson 1976); it was the first recorded meeting with the Caddo peoples. The first expeditions by La Salle in 1687 and the subsequent settlement in the eighteenth century by Europeans continued to document the presence of Native American groups in the area (Aten 1984). French traders and Spanish missionaries encountered the Hasinai, also known as the Neches Angelina, who became allies of the Spanish against the western Apache tribes (Newcomb 1961). The later historical sources identify the Hasinai as one of the two main groups in the area of eastern Texas that fall under the Caddo culture (the primary culture that dominated the Piney Woods area), the other of which is the Kadohadacho (La Vere 1998; Gregory 1986).

The loose cultural group, known as the Attakapans, dominated the majority of the land north of present-day Harris County in what is now Montgomery County. Their language group extended from the Gulf coast to the Trinity and San Jacinto Rivers and they had much in common with the coastal group known as the Karankawa (Aten 1984). The Attakapans were subdivided into regional groups. The Akokisas dwelled primarily on the shores of the Trinity and San Jacinto Rivers. The Patiris group occupied the land north of the San Jacinto valley. The Bidai group dominated the Trinity Valley and to their north was the small group known as the Deadoso. Most of what is known about the Attakapans culture comes from the early accounts of the French explorer DeBellise. They are described as primarily hunter-gatherer groups who relied somewhat on agriculture and fishing (Sjoberg 1951).

In the seventeenth and eighteenth centuries, the Spanish and French used the Native American groups as pawns in the two nations' quest to settle the area (Newcomb 1961). Most destructive for all native groups in the region was the influx of European diseases. When Anglo-American settlers began moving into the area in mass around the 1850s, disease and warfare had decimated the groups to near extinction.

\subsection{Historical Context}

\subsubsection{Development of Harris County}

The lands that would become Harris County comprised the southeastern border of Austin's Colony. In July 1824, 29 titles were granted to lands in future Harris County, with an additional 23 grants made between 1828 and 1833 . These original grants concentrated mainly on the watercourses of the region. The early settlers in the region were mostly whites from the southern United States and slaves of African ancestry (Henson 2010).

In 1826, the first town site in the area, Harrisburgh, was established at the confluence of Buffalo Bayou and Brays Bayou and by the 1830s had become the major port of entry for the region and a transportation hub. Roads ran northwest to the Brazos communities of San Felipe and Washington, east to the ferry landing that crossed the San Jacinto, and west paralleling Brays Bayou to the Oyster Creek 
Community near present day Stafford in Fort Bend County (Henson 2010).

Under Mexican authority, the area surrounding Harrisburg (as it came to be spelled by 1832) was known as the San Jacinto District. The district stretched east from Lynchburg on the San Jacinto River west to the location of present-day Richmond, and from Clear Creek in the south to Spring Creek in the north. After the Texas Revolution, Harrisburgh County was formed December 22, 1836, and encompassed this same territory with the addition of Galveston Island. The county was renamed Harris in December 1839 to honor John Richardson Harris, an early pioneer who had established Harrisburgh. The modern boundaries of Harris County were established in 1838 (Henson 2010).

The founding of the city of Houston by Augustus and John Allen was announced in a newspaper advertisement in August 1836. The brothers managed to convince the delegates of the first Texas Congress to establish the yet-to-be-built Houston as the first, albeit temporary (18371840), capital of Texas. In 1837, Houston also became the seat of Harrisburg County. The town was laid out on a grid plan with streets running parallel and perpendicular to Buffalo Bayou near the confluence of White Oak Bayou. The town grew rapidly from 12 inhabitants and one log cabin in January 1837 to 1500 people and 100 houses four months later. In the 1840s, large numbers of white German and French immigrants settled in Harris County. The Hispanic presence in the region was relatively sparse prior to an influx of immigrants following the Mexican Revolution (Henson 2010).

Initially, the city was not segregated, and slaves lived scattered throughout the city's neighborhoods. There was a separate social structure for the whites and subordinate blacks, which continued beyond the Civil War and Emancipation. Schools, churches, and businesses continued to be segregated and by the end of the nineteenth century, residential segregation was also present. Separate white, black, and later, Hispanic neighborhoods divided the city.

By the mid-nineteenth century, Houston and Harris County had become a center of commerce. Products were imported into the Texas hinterland through Houston after being offloaded from ocean going ships in Galveston. Exports included agricultural products such as cotton, corn, and cow hides. The town became a railroad hub with six railways spreading from 80.5 to 160.9 kilometers (50 to 100 miles) to the northwest, east, west, south, and southeast. In 1873, Houston joined the national rail network when the Houston and Texas Central reached Denison (Henson 2010).

Twentieth century Harris County was driven by the growth of the petroleum industry and excavation of the Houston Ship Channel, which turned the area into a major port of entry (Henson 2010).

\subsubsection{The Development of Memorial Park}

The future Memorial Park and most of the surrounding area was originally part of the John Reinermann Survey. Johann Gerhard (John) Reinermann along with his wife and two sons immigrated to Texas from Germany in 1834. In 1835, he applied for a land grant from Stephen F. Austin to live "on Buffalo Bayou near John Austin's two leagues on $\mathrm{N}$. side of bayou" (Aulbach et al. 2014:79). In 1838, after the conclusion of the Texas Revolution, this land grant was confirmed and issued to John's widow and heirs. The land remained within the Reinermann family, largely intact until the late nineteenth century. The Reinermann homestead and a nearby family cemetery, was located between present day T.C. Jester Boulevard and North Shepherd Drive, north of the Katy Freeway, approximately 2.4 kilometers (1.5 miles) east northeast of the present Memorial Park. An 1847 survey described the Reinermann property as evenly divided between pasture and arable land (Aulbach et al. 2014:81). 
Eventually three rail lines passed through the Reinermann Survey: Houston and Texas Central Railway (1858), Missouri, Kansas and Texas Railroad (1890), and Galveston, Harrisburg and San Antonio Railway (1918). These lines met at what became known as Eureka Junction, located 0.6 kilometers ( 0.4 miles) north of the Memorial Park. It was this junction, tying into the larger national rail network, which would make the area an ideal military training camp location, and it was at this junction that many of the supplies for constructing Camp Logan arrived in 1917 (Aulbach et al. 2014:82-83).

Camp Logan was one of 16 National Guard training camps established at the onset of the United States entrance into World War I. Each camp was to be constructed as quickly as possible and designed to accommodate and train a division of soldiers in preparation for being sent to the European front. Typically, a division numbered up to 28,000 troops and consisted of two brigades of infantry, one brigade field artillery, one regiment of engineers, three machine gun battalions, one field signal battalion, and a number of associated troops from the motorized and horse trains (Thomas 2003).

The camp was named for Major General John A. Logan, a Union Civil War officer and politician from Illinois. In addition to serving in both the United States House of Representatives and Senate, Logan is credited with helping found the Grand Army of the Republic, a Union veterans' organization, and helping establish Memorial Day as a national holiday (John A. Logan Museum 2014).

Land for the camp was leased from the Hogg family, and work began clearing trees and bush in July 1917. Pressed by the urgency to get men to the front, emphasis was placed on speed. Within 13 days, the camps roads and bridges were in place. Gravel was deemed too expensive, so the main roads were paved in crushed shell dredged from Galveston Bay and shipped by rail. Bridges for crossing Buffalo Bayou and smaller tributaries were constructed from timber cut during the clearing of the site. Drainage for the camp was a problem and quickly addressed by the construction of surface ditches. These ditches drained into Buffalo Bayou. The disposal of human waste was done in latrine pits, which were occasionally pumped out and the waste emptied into the City of Houston's sewer system through manholes. In the hot and humid conditions of Houston this system of waste and runoff water disposal created sanitary problems. During the summer of 1918, plans began for a more complex sanitary and sewer system, including 42 kilometers (26 miles) of buried pipe (Aulbach et al. 2014).

By August 1917, 1,329 buildings had been constructed. Photographs accompanying the Camp Logan Completion Report show that these buildings were simple wood frame structures. Most were built on raised pier foundations apart from the latrine and shower buildings which rest on a walled foundation (Rothrock 1918). On August 18, 1917, the first 1,400 troops began to arrive. These advance troops, one company each from regiments of the Illinois National Guard, began clearing and preparing regimental camps (Aulbach et al. 2014).

Progress towards fully opening the camp was delayed by events that came to be known as the "Camp Logan Riot" or "Houston Riot of 1917". When construction began at Camp Logan the 3rd Battalion of the 24th U.S. Infantry were redeployed from New Mexico to Houston to guard the site and materials. This unit was part of the famed African-American Buffalo Soldiers, and there was immediate tension between the soldiers and some of Houston's white residents and in particular the Houston Police Department. On August 23, 1917, a soldier was arrested for interfering with the police attempting to arrest an African-American woman. When a military police officer from the 3rd Battalion questioned a Houston police officer about the arrest he was beaten, shot at, and taken into custody. At the 3rd Battalion camp, east of Camp Logan, rumors began to 
spread that the MP had been killed and that an armed white mob was marching on the camp. A little over 100 soldiers grabbed their weapons and set out to march on downtown Houston. During their march, 15 whites were killed, including four policemen. A fifth officer later died of his wounds. In addition, four soldiers died, two of whom were accidently killed by fellow soldiers, perhaps mistaken for police. After one of these incidents, the killing of Captain Mattes, the march disbanded and most of the men drifted back to camp. The next morning martial law was declared, and the 3rd Battalion was quickly loaded on a train and returned to New Mexico. In three military trials that followed, 118 soldiers were indicted and 110 were found guilty. Of those found guilty, 19 were hanged and 63 were given life sentences. The events of the riot delayed the opening of Camp Logan (Haynes 2010).

At the end of August, commanding officer Major General George Bell informed the War Department that Camp Logan was ready to receive the main body of troops. Throughout September and October, soldiers of the Illinois National Guard arrived in camp and by the end of October troop levels reached nearly 20,000. On October 10, 1917, the Illinois National Guard troops at Camp Logan were reconstituted into the 33rd Infantry Division. By the end of 1917, elements of the 78th Field Artillery, 79th Field Artillery, and the 5th Division brought Camp Logan to its peak occupancy at 33,000 troops. In the spring of 1918, the 33rd Division began its deployment to France and by that summer a second wave of troops began to arrive for training. However, with Armistice on November 11, 1918, these units never completed training and the War Department began a program of demobilization and decommissioning the training centers, including Camp Logan. Troop numbers at Camp Logan had dropped to 11,000 in January 1919 and then to 5,000 in February. By March there were just over 500 troops remaining and the camp was officially closed March 20, 1919. Only a handful of troops remained to complete the liquidation of camp resources which was completed by May. Except for the camp hospital, which was transferred to the Public Health Service, all other buildings were razed or moved (Aulbach et al 2014). Notices run in the Houston Post in the spring and summer of 1919 list numerous buildings from Camp Logan for sale, both as complete structures and dismantled for materials (Houston Post, 7 March 1919:49, 30 July 1919:15).

There are two primary resources documenting the layout of Camp Logan. The camp completion report was produced by Captain W.P. Rothrock, Constructing Quartermaster, and submitted to the War Department (1918). In addition to discussing numerous facets of the construction of Camp Logan, this report includes a highly-detailed map of the camp, and exemplar photos of camp buildings (Appendix A, Figure 1). The Rothrock map provides a detailed accounting of camp buildings, roads, and other infrastructure. Road names used in this report are taken from the Rothrock map.

A second map was produced by Corporal Paul B. Hendrickson (1918), a young soldier stationed at the camp who produced the map as a personal project. On the map he notes with an $X$ the position of "the $14 \mathrm{ft}$ square pyramid tent" that he lived in for eight months. Corporal Hendrickson's map (Appendix A, Figure 2) gives the relative locations of rail lines, roads, bridges, offices, and other buildings. The map also provides the location and layout of each regimental camp. Hendrickson's map also notes unit locations around Camp Logan, providing historical detail not available in Rothrock's map.

The two maps possess a high degree of agreement on the general arrangement of Camp Logan. As might be expected of an official military document produced by an engineer, the Rothrock map has a greater level of detail. Buildings not present on the Hendrickson map are depicted, and structures Hendrickson records only in abstract lines are fully plotted by Rothrock. The Rothrock map 
also includes features such as sewer lines, which were constructed after Hendrickson had departed for the front in France. In contrast, Hendrickson includes information not found on the Rothrock map, including labeling which units were located in specific parts of the camp and some details beyond the borders of the camp itself.

The core of the camp was laid out in a triangle with the main camp entrance at the eastern point. Six regiments were arranged along its south side, five regiments along the northeast side, and four regiments along the western side. Each regimental camp follows roughly the same layout: a line of officer's quarters separated from the rest of the camp by a road, across the road were company buildings such as mess halls, behind the company buildings the bulk of the camp was set aside for rows of tents for enlisted men, at the rear of camp were latrines and shower buildings, finally beyond these were corrals for regimental horses. The division command and hospital buildings were located at the eastern end of the camp, just outside the modern boundaries of Memorial Park. Immediately to the west, and just inside the Memorial Park boundary, were several buildings operated by the Red Cross, the camp post office, and a library. Other buildings scattered across the camp included those run by social organizations such as the YMCA and Knights of Columbus. The interior of the camp triangle, now mostly occupied by the Memorial Park Golf Course, was set aside as drill grounds and bisected by the Central Road. The Hendrickson map likewise shows a small set of training trenches located in what is now the southwest corner of the Memorial Park Golf Course.

Other portions of Camp Logan were located well beyond the modern Memorial Park boundaries (Figure 3-1). An artillery and rifle range were constructed approximately 11 kilometers (7 miles) to the west in an area now largely occupied by Addick's Reservoir and the Memorial City neighborhood. A network of training trenches was built 0.5 kilometers $(0.3$ miles) north of the main camp, roughly from the junction of Old Katy and Hempstead Roads and extending northwest to Post Oak Road. The 1.4kilometer (0.9-mile) trench system was designed to prepare trainees for trench warfare on the European western front. Large portions of the trenches remain visible on historic aerials until the 1950s when they became covered by commercial development and the construction of Interstate 610 (Google, Inc. 2019). The Remount Depot, where the bulk of the camp's horses were housed, was located in an area between the practice trenches and the main camp's northwest corner. Most of this area was built over in the construction of Interstate 10. The Hendrickson map also indicates that there was additional drill space located on the south side of Buffalo Bayou, in what is now Houston's River Oaks neighborhood.

Almost immediately after the closing of Camp Logan, calls began to be made for setting the land aside as a park in memory of the soldiers who had been stationed there and served during World War I. The most strident of these advocates was Catherine Mary Emmott. In 1924, Will and Mike Hogg, along with Henry Stude, purchased much of the property and then sold it to the City of Houston at cost, allowing for the formation of Memorial Park. Although plans were drawn up as early as 1924, the Great Depression delayed much of the work until the Works Progress Administration put five hundred men to work constructing the golf course and other facilities in a first step in the development of Memorial Park (Memorial Park Conservancy 2018). Interstate construction in the 1960s would heavily impact the park's western and northern edges, including areas that were formerly part of Camp Logan (Google, Inc. 2019). 
REMOVED FROM PUBLIC COPY

Outlying Camp Logan facilities. 


\subsection{Site File and Literature Review}

The site file research and literature review were completed to identify previously recorded archaeological sites, National Register-listed properties, and previous investigations within 1.6 kilometers ( 1 mile) of the project area. This work was conducted by reviewing data available on the Texas Online Archeological Sites Atlas, an online resource maintained by the THC. Historical aerial imagery was also consulted via Google Earth (Google, Inc. 2019).

This work was used to provide a historical context to the cultural resources survey, and additional documentary research was conducted in order to provide an understanding of the development and history of the surrounding area. This research then was used to prepare an overview history of the area and provided an understanding of the contextual framework of the area's prehistory and history. Additional documentary research was conducted to provide an understanding of the development and history of the immediately surrounding area of Memorial Park, and to develop a regional context of the area and discuss the significance of previously identified resources, particularly Camp Logan.

\subsection{Field Methods}

Georeferenced overlays of Corporal Paul B. Hendrickson's 1918 map of Camp Logan and the map included in Rothrock's completion report (Appendix A), historical maps, and historical images, provided a detailed historical context used to guide the cultural resources survey. Also useful was the detailed history of Camp Logan prepared by Lovis Aulbach, Linda Gorski, and Robbie Morin (2014). Field observations and conditions further guided additional testing efforts within the Area of Potential Effects (APE).

\subsubsection{Intensive Pedestrian Survey}

Survey of the APE consisted of pedestrian walkover and photo-documentation, and shovel testing. A handheld Global Positioning System (GPS) receiver capable of sub-meter accuracy data recording was used to assist in survey. Survey transects were placed approximately 50 meters (100 feet) apart, while shovel test excavations and visual observation took place at 50-meter (160-foot) intervals. Additional judgmental excavation of shovel tests was placed as determined by making an assessment of the archaeological potential across the tract and met or exceeded the THC minimum survey standards which require at least one shovel test per every 0.8 hectares $(2$ acres).

Shovel testing consisted of 30-centimeter (11inch) diameter hand-excavated tests completed to a maximum depth of 100 centimeters (39.3 inches) into the underlying substratum. Vertical control was maintained by excavating each shovel test in 10-centimeter (4-inch) arbitrary levels. One wall of each shovel test was profiled, and the walls and floor of each shovel test were inspected for color or texture change potentially associated with the presence of cultural features. When possible, soils were screened through 0.64 -centimeter ( $1 / 4$-inch) wire mesh and descriptions of soil texture and color followed standard terminology and the Munsell soil color charts (2005). All field data were recorded on standardized field forms to match mapped location of shovel tests and other recorded features. All shovel tests were backfilled after excavation and documentation. The excavated shovel tests, observation points, and any other cultural remains were placed on field maps and points were taken with the aid of a GPS data collector. 


\subsubsection{Site Definition}

Most fieldwork was conducted within the boundaries of previously recorded Site 41HR614, Camp Logan, thus site definition primarily entailed the identification of surfacevisible archaeological features based on contemporary records (including period mapping) and the results of previous investigations. Subsurface testing, combined with intensive pedestrian assessment, was utilized as a supplemental method to test the accuracy of these data as applied to the current project configuration. In situations where cultural material was encountered outside the boundaries of a known site, systematic steps were taken to define their extent, limits, and general character within the confines of the APE. Additional delineation shovel tests were excavated in four radiating directions at an interval of 10 meters (32.8 feet) within the confines of the APE. In general, two sterile shovel tests were used to define a site's size and extent. At a minimum, between six and eight delineation shovel tests were to be excavated unless surrounding landforms or topography suggested the presence of a natural site boundary.

For each cultural resource identified, including structures or other resources within or immediately adjacent to the APE, photographs were taken of the general vicinity and of any visible features. A sketch map was prepared showing site limits, feature locations, permanent landmarks, topographic and vegetation variation, sources of disturbances, and total number of tests performed within the site. Diagnostic artifacts recovered from shovel tests were to be collected, however no artifacts were recovered which would benefit from further laboratory analysis. Non-diagnostic artifacts were photographed in the field and returned to the backfilled shovel test. In situations where a large number of non-diagnostic artifacts were recovered, a representative selection was photographed. Locations of all positive shovel tests were recorded with the GPS.

Following the conclusion of each survey all feature, and site boundary locations were added to a master GIS file and table. Feature were sequentially numbered in each of larger project areas within Memorial Park. The table with a map of project areas is included in Appendix B.

\subsection{Laboratory Analysis and Curation}

No diagnostic or non-diagnostic artifacts were collected in the course of the current survey; therefore, no discussion of laboratory analysis is included in this report. As a project permitted through the THC, Gray \& Pape submitted project records to the Center of Archaeological Studies at Texas State University in San Marcos, Texas. 


\subsection{SITE FILE AND LITERATURE REVIEW}

\subsection{Previously Recorded Surveys}

Consultation with the Texas Archeological Sites Atlas revealed 17 cultural resource surveys previously conducted within a 1.6-kilometer (1mile) buffer of Memorial Park (Figure 1-1; Table 5-1). Of these, nine of the surveys overlap with the boundaries of the park. In 1989, Moore Archeological Consulting, Inc. (MAC), conducted an extensive survey of portions of Memorial Park. This survey noted numerous structural remains but did not include a complete mapping of every foundation and conducted only minimal shovel testing (Moore et al. 1989). MAC conducted a second survey of Memorial Park in 2001, though this survey was focused on determining the relative potential of different areas of the park for producing prehistoric cultural remains. They concluded that the greatest potential for intact prehistoric sites within the park was along ridges formed between drainages and gullies in the southern portions of the park. A single historic site (41HR885) was recorded during the course of the survey and will be discussed in the following section (Moore and Sanchez 2001).

In 2008, J.K. Wagner \& Company, Inc. (J.K. Wagner) conducted an intensive pedestrian survey, including shovel testing, of the area of the park west of the Interstate 610 Loop. This area had previously served as the park's archery range. During the course of their survey, J.K. Wagner identified several historic features including the remains of a water tank and a Boy Scout Pavilion. They also attempted to relocate a previously recorded prehistoric site (41HR617) but only a single flake, in a disturbed context, was recovered. No site designation was requested for the historic component (Molineu et al. 2010).

In 2012, MAC conducted a small survey of the future footprint of the Memorial Park Running Trails Center near the western edge of the park along Memorial Drive. No sites or cultural material were identified during the course of the survey (Mangum 2012).

In 2015, Rice University students and faculty conducted an archaeological survey and test excavation as part of an archaeological field techniques course under Texas Antiquities Permit \#7161. Work focused on the area in the northwest portion of the park where the $370^{\text {th }}$ Infantry of the 93 Division, an African-American battalion, was believed to be encamped. Work included pedestrian survey, magnetometry survey, shovel testing, and test unit excavation. In addition to relocating many of the concrete foundations previously identified by MAC in 1989, shovel testing and test units recovered mostly modern material. However, a small number of historic artifacts were recovered, including ceramic electrical tubing, iron nail fragments, and brick fragments. A porcelain mortar bowl, dated between 1900-1930, was found on the surface near the railroad tracks (Fleisher 2015).

In 2016, SWCA Environmental Consultants (SWCA) conducted an intensive pedestrian survey, including shovel testing, of portions of the Houston Arboretum \& Nature Center, which occupies most of the southwestern portion of Memorial Park. One new historic archaeological site (41HR1181) was recorded during the course of the survey. The site was described as a twentieth-century historic dump (McLeod et al. 2017). The site will be discussed further in the following section.

In 2016, MAC conducted an intensive pedestrian survey, including shovel testing and metal detecting. Work primarily focused in the eastern portions of the park in advance of a planned realignment of East Memorial Loop Drive and the construction of a detention pond and other related drainage features. A smaller area along North Picnic Lane was also surveyed (Mangum et al. 2017). MAC recovered 2,686 
historic artifacts: 854 were categorized as Camp Logan Related, 126 as Possibly Camp Logan Related, 1087 as Uncertain, and 156 as Post Camp Logan Related (Mangum et al. 2017:50). The most commonly recorded artifacts included: wire nails $(n=646)$, pieces of coal, coke, and slag $(n=249)$, and indeterminate metal artifacts $(n=112)$. All cultural material was considered to be part of the previously designated $41 \mathrm{HR} 614$.

Gray \& Pape conducted two intensive pedestrian surveys with shovel testing in Memorial Park in 2016. The first was in the area designated Memorial Groves by the MPC (Quennoz and Valenti 2018). The second was a compliment to the 2016 MAC survey in the Eastern Glades area (Quennoz and Valenti 2017). Twenty-seven features were identified during the course of the Memorial Groves survey and were determined to be part of the
Camp Logan sanitation system, including the concrete foundations for showers and latrines. Deep testing was carried out using a hand auger in an area believed to have been the location of Camp Logan pit latrines, but no such deposits were identified. All cultural material was considered to be part of the previously designated 41HR614, Camp Logan site (Quennoz and Valenti 2017).

The Eastern Glades survey identified wire nail fragments in three shovel tests as well as a small, low density, surface scatter of brick and brick fragments. The remains of a former Camp Logan road were recorded between Crestwood Drive and Memorial Park Loop. Several concrete park benches were also recorded, though the exact age of these benches remains unclear (Quennoz and Valenti 2017). All material was considered to be part of the previously designated $41 \mathrm{HR} 614$.

Table 5-1. Previously Recorded Surveys within 1.6 Kilometers (1 Mile) of Memorial Park, Harris County, Texas.

\begin{tabular}{|c|c|c|c|c|c|c|}
\hline $\begin{array}{l}\text { Survey } \\
\text { Type }\end{array}$ & $\begin{array}{c}\text { Investigating Firm/ } \\
\text { Agency }\end{array}$ & $\begin{array}{l}\text { Field } \\
\text { Work } \\
\text { Date } \\
\end{array}$ & $\begin{array}{c}\text { TAC } \\
\text { Permit } \\
\text { Number }\end{array}$ & $\begin{array}{l}\text { Report } \\
\text { Author }\end{array}$ & $\begin{array}{l}\text { Sponsoring } \\
\text { Agency }\end{array}$ & $\begin{array}{l}\text { Report } \\
\text { Published }\end{array}$ \\
\hline Area & MAC & 1989 & 738 & Moore et al. & SLA Studioland & 1989 \\
\hline Linear & $\begin{array}{c}\text { Federal Highway } \\
\text { Administration (FHA) }\end{array}$ & 1993 & NA & NA & $\mathrm{FHA}$ & NA \\
\hline Area & $\mathrm{NA}$ & 1994 & $\mathrm{NA}$ & NA & NA & NA \\
\hline Linear & $\begin{array}{c}\text { Texas Water } \\
\text { Development Board } \\
\text { (TWDB) }\end{array}$ & 1996 & 1641 & Davis & TWDB & 1996 \\
\hline Linear & $\begin{array}{c}\text { United States Army } \\
\text { Corps of Engineers } \\
\text { (USACE) }\end{array}$ & 1999 & NA & NA & USACE & NA \\
\hline Area & MAC & 2001 & 2695 & $\begin{array}{l}\text { Moore and } \\
\text { Sanchez }\end{array}$ & City of Houston & 2002 \\
\hline Area & Wagner & 2008 & 5072 & $\begin{array}{l}\text { Molineu et } \\
\text { al. }\end{array}$ & $\begin{array}{l}\text { Memorial Park } \\
\text { Conservancy }\end{array}$ & 2010 \\
\hline Area & HRA Gray \& Pape & 2011 & NA & $\begin{array}{l}\text { Nash and } \\
\text { Spalding }\end{array}$ & $\begin{array}{l}\text { Harris County } \\
\text { Flood Control } \\
\text { District }\end{array}$ & 2015 \\
\hline Area & MAC & 2012 & 6253 & Magnum & City of Houston & 2012 \\
\hline Area & HRA Gray \& Pape & 2012 & 6459 & $\begin{array}{l}\text { Balakirova } \\
\text { and Bludau }\end{array}$ & USACE & 2015 \\
\hline Area & HRA Gray \& Pape & 2014 & 6744 & Tuttle & $\begin{array}{l}\text { Harris County } \\
\text { Flood Control } \\
\text { District }\end{array}$ & 2015 \\
\hline Area & Rice University & 2015 & 7161 & Fleisher & $\mathrm{NA}$ & $\mathrm{NA}$ \\
\hline
\end{tabular}




\begin{tabular}{|c|c|c|c|c|c|c|}
\hline $\begin{array}{c}\text { Survey } \\
\text { Type }\end{array}$ & $\begin{array}{c}\text { Investigating Firm/ } \\
\text { Agency }\end{array}$ & $\begin{array}{c}\text { Field } \\
\text { Work } \\
\text { Date }\end{array}$ & $\begin{array}{c}\text { TAC } \\
\text { Permit } \\
\text { Number }\end{array}$ & $\begin{array}{c}\text { Report } \\
\text { Author }\end{array}$ & $\begin{array}{c}\text { Sponsoring } \\
\text { Agency }\end{array}$ & $\begin{array}{c}\text { Report } \\
\text { Published }\end{array}$ \\
\hline Area & MAC & 2016 & 7347 & $\begin{array}{c}\text { Mangum et } \\
\text { al. }\end{array}$ & Harris County & 2016 \\
\hline Area & SWCA & 2016 & 7592 & $\begin{array}{c}\text { McLeod et } \\
\text { al. }\end{array}$ & City of Houston & 2016 \\
\hline Area & Gray \& Pape, Inc. & 2016 & 7686 & $\begin{array}{c}\text { Quennoz } \\
\text { and Valenti }\end{array}$ & $\begin{array}{c}\text { Memorial Park } \\
\text { Conservancy }\end{array}$ & 2016 \\
\hline Area & Gray \& Pape, Inc & 2016 & 7574 & $\begin{array}{c}\text { Quennoz } \\
\text { and Valenti }\end{array}$ & $\begin{array}{c}\text { Memorial Park } \\
\text { Conservancy }\end{array}$ & 2017 \\
\hline
\end{tabular}

In 2017 and 2018, Gray \& Pape conducted intensive pedestrian and shovel tests surveys in multiple areas of the park under Annual Permit 7978 (Quennoz 2018). Survey resulted in the identification of numerous features associated with Camp Logan (41HR614) as well as updates to the previously recorded archaeological sites 41HR617 and 41HR885 (see below). One new prehistoric site (41HR1217) was also identified.

\subsection{Previously Recorded Archaeological Sites}

The site boundaries of Camp Logan (41HR614), a State Antiquities Landmarkdesignate (\#8200003264), occupy most of the core of Memorial Park in six discreet areas between the railroad tracks to the west, Interstate 10 to the north, residential neighborhoods to the east, and the large network of drainages leading to Buffalo Bayou to the south. Numerous concrete foundations, mostly from camp showers and latrines, brick and mortar manholes, camp roads and ditches have been recorded. Subsurface finds consist of a mix of early twentieth through late twentieth century material. The oldest material most commonly encountered are wire nails and ceramic insulators. Subsurface finds are generally shallow and often in mixed or disturbed contexts.

There are six additional sites in the area surrounding of Memorial Park, four of these sites are within the park itself (Table 5-2, Figure 1-1). The first (41HR617) was recorded as a Late Archaic site located on the former Memorial Park Archery Range, on the south/east bank of Buffalo Bayou. The site was originally excavated in 1939, recovering around a dozen Kent and Gary type points. The site received a trinomial and was mapped at its current location in 1988 based solely on a verbal description of the location. In 2008, attempts to relocate the site failed to find any evidence, and those authors believed that the mapped location was incorrect (Molineu et al. 2010). During a 2017 Gray \& Pape revisit, previously recorded above ground historic-age features including a water tank, metal shed, and boy scout pavilion were photographed and mapped. These features were included within an expanded $41 \mathrm{HR} 617$ site boundary. No evidence of the prehistoric component previously associated with $41 \mathrm{HR} 617$ was identified during the Gray \& Pape investigation (Quennoz 2018).

Site 41 HR885 was recorded by MAC in 2002 and is located between Woodway Drive and an unnamed north/south running drainage that ultimately flows into Buffalo Bayou. At the time, a cursory examination was undertaken, and it was described as the remains of a twentieth century trash dump. No shovel tests were excavated but based on an examination of one of several looters' pits, the depth of the cultural deposits was believed to be between 0 and 30 centimeters ( 0 and 12 inches) below the 
surface. Although some early twentieth century material was noted, surveyors believed that the bulk of the material was from the 1960s and possessed low potential research value (Moore and Sanchez 2002). A revisit of the site by Gray \& Pape in 2017 resulted in a reassessment of 41 HR885 as an early twentieth century dump site with deep, intact deposits up to 1 meter (3 feet) in depth, that may be contemporary or immediately post-date the Camp Logan period. Gray \& Pape recommended that the site be avoided by MPC planned activities and be periodically monitored to ensure that no further looting took place (Quennoz 2018).

Site $41 \mathrm{HR} 1181$ was recorded by SWCA in 2016 and located in the northwestern section of the Houston Arboretum and Nature Center. SWCA described the site as a diffuse and poorly organized historic scatter or dump, dating to the early part of the twentieth century (McLeod et al. 2017).

Site $41 \mathrm{HR} 1217$ was recorded by Gray \& Pape in 2018 as a low-density prehistoric lithic and ceramic scatter located on the edge of a terrace overlooking a large drainage near its junction with Buffalo Bayou. At least one of the sherds was identified as Goose Creek Incised, dating the site to the Late Prehistoric period (Quennoz 2018).

\subsection{Additional Cultural Resources}

One National Register District and five National Register Properties are located within the 1.6kilometer (1-mile) research area surrounding Memorial Park (Figure 1-1). These include: Bayou Bend National Register District, Hugo V. Neuhaus, Jr. House National Register Property, William L. Clayton Summer House National Register Property, the Charles W., Sr. and Mary Duncan House, Margarite Meachum and John S. Mellinger House, and Cleveland Harding Sewall House National Register Property. None of the properties are within or immediately adjacent to Memorial Park.

There are three cemeteries located within the 1.6-kilometer (1-mile) research area surrounding Memorial Park. These include Morse-Bragg Cemetery, Saint Martin's Episcopal Cemetery, and Beth Yeshurun-Post Oak Cemetery. None of the listed cemeteries are located within or immediately adjacent to Memorial Park.

Table 5-2. Previously Recorded Archaeological Sites within 1.6 Kilometers (1 Mile) of Memorial Park, Harris County, Texas.

\begin{tabular}{|c|c|c|c|c|}
\hline $\begin{array}{c}\text { Trinomial/ } \\
\text { THC } \\
\text { Designation }\end{array}$ & Resource Type & Sponsoring Agency & $\begin{array}{c}\text { Original Recorder(s) and } \\
\text { Date }\end{array}$ & NRHP Status \\
\hline $41 \mathrm{HR} 617$ & Late Archaic & Unknown & Black - 1939 & Undetermined \\
\hline $41 \mathrm{HR} 1181$ & Historic Scatter & City of Houston & Mattox and Kennedy - 2016 & Not Eligible \\
\hline $41 \mathrm{HR} 885$ & Historic Dump & Unknown & $\begin{array}{c}\text { Sanchez and Schexnayder - } \\
2002\end{array}$ & Undetermined \\
\hline $41 \mathrm{HR614}$ & World War I Camp & City of Houston & Moore - 1989 & Eligible \\
\hline $41 \mathrm{HR} 791$ & Prehistoric Scatter & $\begin{array}{c}\text { Texas Water } \\
\text { Development Board }\end{array}$ & Huebner and More - 1996 & Undetermined \\
\hline $41 \mathrm{HR} 1158$ & Shell Midden & Private & Beene - 2015 & Undetermined \\
\hline $41 \mathrm{HR} 139$ & Prehistoric Camp Site & Unknown & Unknown & Undetermined \\
\hline $41 \mathrm{HR} 1217$ & Prehistoric Camp Site & $\begin{array}{c}\text { Memorial Park } \\
\text { Conservancy }\end{array}$ & Hilton - 2018 & Undetermined \\
\hline
\end{tabular}




\subsection{RESULTS OF SPORTS COMPLEX SURVEY}

The APE for the Sports Complex project is located on the Houston Heights, TX 7.5-minute USGS topographic quadrangle map (Figure 11). The 12.4-hectare (30.6-acre) APE is defined on its north side by Interstate 10, on its west side by Southern Pacific Rail lines, and its southern and eastern ends by Memorial Loop Drive. The western and eastern ends of the APE are a mix of pine and oak woods with a heavily overgrown understory of briar and yaupon. The middle portion of the APE has an oval asphalt timing track and a practice baseball field. Running the length of the APE, along its southern edge, is developed park land that includes a 3-meter (10-foot) wide crushed brick running trail, plantings, park benches, and a mowed and manicured landscape. At the time of survey, the MPC planned to conduct standard park maintenance activities including mechanical clearing of the invasive understory, foliar application of herbicide, and new plantings.

\subsection{Previous Cultural Resource Work}

Two previously conducted cultural resource surveys overlap in part with the Sports Complex project area. In 1989, MAC conducted a pedestrian survey of several areas of Memorial Park, including 6 hectares (15 acres) that overlap with the eastern third of the current APE. MAC identified no historic features within the area, and two excavated shovel tests were negative for cultural material (Moore et al. 1989). In 2002, MAC conducted a largely pedestrian survey of Memorial Park in order to determine relative archaeological potential within the park. The northern portion of the park where the APE is located, far removed from Buffalo Bayou and its tributaries in the south of the park, was considered to have a low potential for prehistoric sites (Moore and Sanchez 2002).

\subsection{Current Effort}

The Sports Complex survey consisted of pedestrian walkover survey and shovel testing. Pedestrian walkover survey focused on identifying the remains of above-ground features as well as serving as reconnaissance for the shovel test survey which followed. The survey effort also made use of a georeferenced map included with the Camp Logan Completion Report in identifying and interpreting possible Camp Logan features (Figure 6-1) (Rothrock 1918). The APE crosses what would have been four different unit blocks arranged along the camp's north side. The westernmost portion of the APE overlaps with what were officer's tents and mess halls for the northwestern-most unit block. The APE crosses the next block east through an area that would have been for the enlisted men's tents. Continuing east was an area set aside for latrines, lavatories, and toilets. The westernmost portion of the APE corresponds with the stables of that unit block.

Four historic features were recorded during the course of the survey (Figure 6-2). Feature 1 was an area of exposed crushed shell on the ground surface. Based on the location in comparison to the Camp Logan Completion Report map, this is likely the remains of a Camp Logan road. In this case Twenty-Ninth Street, which was the main east/west running road along the north side of the camp. The exposed crush shell covered an area of less than 3 meters (10 feet) across, and there was no discernable road structure remaining as has been observed in other areas of the park (Quennoz 2018). Feature 2 is a rectangular concrete foundation divided in half by a wall creating two interior squares (Figure 6-2). The feature is approximately 4.25 by 1.92 meters $(14.0$ by 6.3 feet) and with walls 19.5 centimeters (7.7 inches) thick. The exposed remains extended approximately 15 centimeters (6 inches) above the current ground surface. The base of the 
REMOVED FROM PUBLIC COPY

Project area location on 1919 map of Camp Logan 
REMOVED FROM PUBLIC COPY

Sports Complex survey results 
structure could not be determined due to wet soils but extends at least 85 centimeters (33 inches) below the surface. Feature 2 is nearly identical to two similar features (Feature 3, Feature 26) identified in the Bayou Wilds project area during a previous Gray \& Pape survey within Memorial Park (Quennoz 2018). The only difference is that the currently considered structure does not have any brick or support bolts associated with it as seen in the previous examples. These features have been interpreted as grease traps, located near the Camp Logan mess halls. The Camp Logan Completion Report states that 18, brick made, regimental grease traps were constructed for the mess halls, and lists dimensions the same as those recorded for the Features (Rothrock 1918).

Feature 3 is a concrete signpost in the northeast portion of the APE, near the Interstate 10 East exit ramp onto Westcott Street and Washington Avenue (Figure 6-2). The obelisk shaped post is labeled "Westcott" and "North Entrance." Similar concrete signposts can be found throughout Houston. The majority of these posts were part of a Depression Era, federally funded program, directed by Houston mayor Oscar Holcombe (Holcombe 1940). This particular signpost marked the original northern entrance to the park, constructed in the 1930s as part of the first phase of Memorial Park's development. This entrance was later shifted approximately 70 meters (230 feet) to the southeast, first during the construction of Interstate 10 in the 1970s and then into its current configuration between 1989 and 1995 (Google, Inc. 2019).

Feature 4 and Feature 5 are both ditches that likely have their origins in the Camp Logan period. Feature 4 is a ditch approximately 112 meters (367 feet) long running roughly southeast to northwest through the middle portion of the APE and continuing beyond the APE to southeast. Depth and width of the Feature varies widely across its length. Based on location, the ditch probably has its origin as a robber trench created during the removal of sewer pipe connecting latrines across the northern portion of Camp Logan. Since that time the trench has been heavily modified and is impacted by road construction, trail construction, and the creation of the asphalt timing track. Feature 5 is a ditch running along the southwestern edge of the APE. This ditch originally ran along a camp road dividing the northern and western lengths of the camp. The ditch is approximately 83 meters (272 feet) long, 1 meter ( 3.3 feet) wide, and 0.5 meters (1.6 feet) deep, running between the utility corridor and developed park lands. Sitting atop the lip of Feature 5 is a disarticulated piece of concrete measuring approximately 1 meter by 1 meter by 0.50 meters ( 3.3 feet by 3.3 feet by 1.6 feet). Several similar blocks were previously recorded in the Bayou Wilds area of the park near the rugby field (Quennoz 2018). A slight lip running around one edge of these blocks suggests they were poured into excavated holes, perhaps to be used as footers. The exact purpose and age of these blocks remains unclear; however, they have clearly been removed and left on the surface out of their primary context.

A total of 71 shovel tests were attempted across the APE; one was left unexcavated due to inundation, five were positive for cultural material, and the remainder were negative for cultural material (Figure 6-2). In general, shovel tests were consistent with soils mapped for the area. A typical soil profile is demonstrated by Shovel Test A16. A dark grayish brown (10YR4/2) sandy loam extends to 10 centimeters (4 inches) below the surface and was underlain by a brown (10YR5/3) sandy loam to 40 centimeters (16 inches) below the surface. To a depth of 60 centimeters (24 inches) below the surface was a mottled dark grayish brown (10YR4/2) and brownish yellow (10YR6/8) sandy clay loam (Figure 6-3). Tests excavated along the southern length of the APE, in areas with the most development, were the most likely to display disturbed or fill soils.

Three of the five positive shovel tests (B 1 4, C8, D9) produced non-diagnostic historic material in disturbed soils. Recorded material included window glass, pieces of concrete, and an iron 
nail. Historic aerials from 1953 show that these shovel tests coincide with an area of the APE that was heavily graded and reworked (Google, Inc. 2019). Shovel Test A9 produced a single black plastic button at 25 centimeters (10 inches) below the surface in a very small, less than 5 centimeters ( 2 inch) thick, burn layer. Black plastic buttons did not become part of the U.S. Army Uniform until after World War I, so the find is not likely related to Camp Logan (Hwang 2012). Shovel Test C5 revealed the buried remains of a vertical wood post, approximately 30 centimeters (12 inches) in diameter. The post began immediately below the topsoil and continued to the base of the shovel test at 50 centimeters (20 inches) below the surface. Compared to its geo-refenced location on the Camp Logan Completion Report Map (Rothrock 2018), and its size, the post is most likely the remains of a utility pole that ran alongside the road crossing the northern portion of the camp.

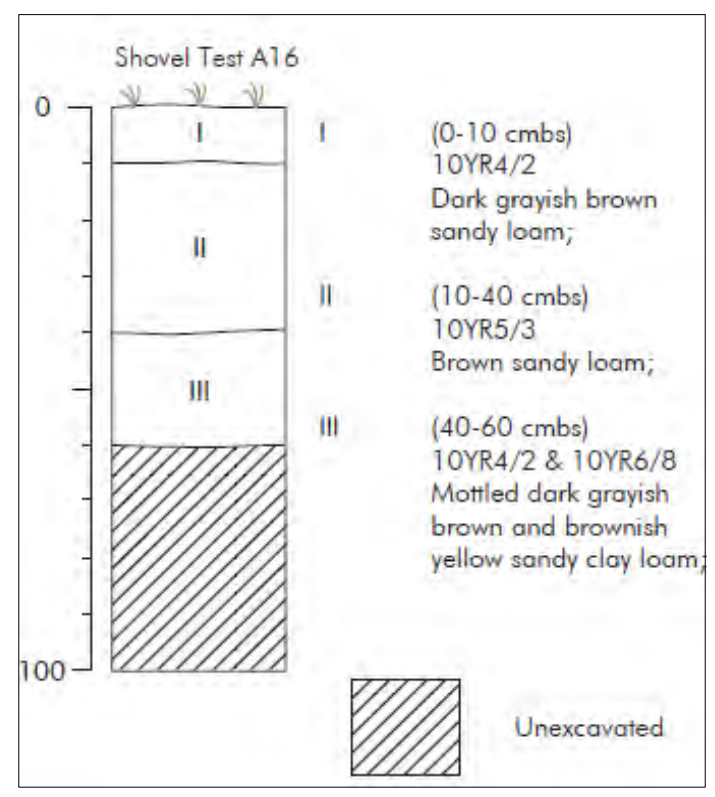

Figure 6-3. Soil profile for Shovel Test A16.

\subsection{Conclusions and Recommendations}

Based on the results of these surveys, Gray \& Pape would make the following recommendations. Protective fencing with a 5meter (16-foot) buffer should be emplaced around Feature 2 and Feature 3. Clearing within this buffer should be undertaken only by hand. Crews operating machinery in this area should be made aware that there might be additional features obscured during survey by the dense vegetation. The ditch features (Feature 1 and Feature 4) are unlikely to be impacted by clearing activities, though caution should be used operating heavy machinery near these features, particularly in wet conditions.

Given the above precautions, Gray \& Pape believes that the discussed cultural resources within the APE will not be affected by MPC plans. If the MPC adjust plans in the future to include activities that will impact the previously identified features or that will include deep impacts within the APE, additional work would be required.

Findings were submitted to the THC for review and concurrence was received on October 8, 2018. 


\subsection{RESULTS OF BAYOU WILDS - EAST SURVEY}

The APE for the Bayou Wilds - East project is located on the Houston Heights, TX 7.5-minute USGS topographic quadrangle map (Figure 1 1). The 76-hectare (189-acre) APE is defined on its north side by Memorial Drive, to the east by Crestwood Drive, to the south by Buffalo Bayou, and on its west by the Memorial Park Purple Trail. The project area consists of level flood plains dissected by three large drainages and numerous subsidiary drainages. These drainages tend to run northwest to southeast, emptying into Buffalo Bayou. The largest of these erosional drainages cross the entire APE north to south; and can be up to 50 meters ( 166 feet) wide and 6 meters (20 feet) deep. Vegetation consists of an oak and pine overstory with a heavily overgrown understory of yaupon, holly, and briar.

Development within the APE is concentrated around the Picnic Loop area and the maintenance facility maintained by the Memorial Park Conservancy and the Houston Parks Board. The Picnic Loop area consists of paved roads and parking lots, picnic areas, bathrooms, and associated utilities. The maintenance yard is primarily used for equipment storage, office space, greenhouses, and associated utilities. Other impacts to the APE include a gas pipeline that cuts across the eastern third of the project area from Memorial Drive to Buffalo Bayou and several City of Houston wastewater lines located in the areas immediately south and east of the maintenance yard (Houston Public Works 2019). At the time of survey, the MPC planned to conduct standard park maintenance activities including mechanical clearing of the invasive understory, foliar application of herbicide, and new plantings.

Soils mapped within the APE include: Bissonnet loam within the level floodplain portions of the project area and Atasco fine sandy loam along the dissected drainages and Buffalo Bayou ([SSS NRCS USDA 2019). Bissonnet series soils are very deep, poorly drained soils formed in the loamy fluviomarine deposits of the Pleistocene age Beaumont Formation. They are typical of the flats of coastal plains. Atasco series soils are very deep, moderately well drained soils formed in loamy fluvial deposits that are typical of river valleys and terraces (Wheeler 1976; SSS NRCS USDA 2019).

\subsection{Previous Cultural Resource Work}

In 1989, MAC conducted a primarily pedestrian survey of several areas of Memorial Park. Although the entirety of Memorial Park was discussed as part of that project, the current APE was not included in the areas physically surveyed (Moore et al. 1989). In 1996, the TWDB conducted a linear crossing the eastern half of the APE. No additional information is available on the Texas Archeological Sites Atlas concerning this project.

In 2002, MAC conducted a second pedestrian survey of Memorial Park in order to determine relative archaeological potential within the park. Within the current APE they identified what they believed to be moderate and high probability areas for intact prehistoric cultural deposits. The areas believed to have the highest potential were those in the upland margin, along the 15-meter (50-ft) contour interval and extending upslope for a distance of approximately 150 meters (492 feet). The survey also identified an area at the eastern edge of the APE as having soils "characterized by extensive, deep filling with debris and modern trash" (Moore and Sanchez 2002).

\subsection{Current Effort}

The Bayou Wilds - East survey consisted of pedestrian walkover survey and shovel testing survey. Pedestrian walkover survey focused on identifying the remains of above ground features as well as serving as reconnaissance for 
the shovel test survey which followed. The survey effort also made use of a georeferenced map included with the Camp Logan Completion Report (Figure 7-1) (Rothrock 1918) in identifying and interpreting possible Camp Logan features. The historical record and maps indicate that northern portions of the current area of study was utilized during the Camp Logan period. The APE overlays portions of four regimental blocks along the southern side of the camp. Most of this area would have been occupied by enlisted men's tents. However, structures shown on the map include latrines, showers, stables, a regimental infirmary, and several camp streets, including Fifth Street which crossed over Buffalo Bayou. Historical aerial imagery indicates that this area is also among the most intensively developed in Memorial Park, largely related to the construction of the Picnic Loop area and the Memorial Park Conservancy and Houston Parks Board maintenance yard. Picnic Loop was first constructed sometime between 1930 and 1944. The maintenance yard first appears sometime between 1944 and 1953. Both the Picnic Loop and the maintenance yard have been modified and expanded numerous times since their initial construction (Google, Inc. 2019).

A total of 362 shovel tests were attempted across the APE; 60 were left unexcavated due to slope, inundation, or obvious disturbance, and 44 were positive for cultural material. The remaining tests were negative for cultural material. As the result of the survey, the site boundaries for $41 \mathrm{HR} 614$ and $41 \mathrm{HR} 1217$ were expanded and five new sites; four prehistoric and one multi-component, were identified. Two historic-age structures were also recorded (Figure 7-2). The survey plan called for shovel tests at 50-meter (164-foot) intervals across the APE. However, after the initial grid survey was completed it became apparent that the prehistoric sites were occurring on interfluve ridges between the 12 and 15-meter (40 and 50-foot) contour interval. Therefore, a series of judgmentally placed shovel tests were excavated along this contour, shrinking the shovel test interval to 25 meters (82 feet) in those areas most likely to produce prehistoric material. Delineation tests were not excavated for shovel tests in which non-diagnostic historic artifacts were recovered (wire nails, small vessel glass fragments, bottle caps etc.). These items most often occurred in areas actively used throughout the twentieth century, were shallowly buried, in heavily modified areas of the park, and could not be differentiated from modern park refuse.

Site $41 \mathrm{HR} 614$ is primarily associated with the remains of the World War I training facility Camp Logan, which was active between 1917 and 1919. The site as originally recorded was divided into six discrete parcels located within Memorial Park. These boundaries were drawn based on the footprint of areas surveyed by MAC in 1989, but because individual features were not mapped, they were not representative of the actual distribution of cultural features within those survey footprints (Moore et al. 1989). During the current survey effort, multiple features believed associated with Camp Logan were identified. As a result of the current survey, previous Gray \& Pape surveys (Quennoz and Valenti 2017, Quennoz and Valenti 2018, and Quennoz 2018), and discussions with the THC; Gray \& Pape believes that the site boundaries should be drawn to include the entirety of the Camp Logan footprint within the current boundaries of Memorial Park (Figure 7-3).

Ten new Features were recorded within the revised boundaries of $41 \mathrm{HR} 614$. Features 1, 2, and 4 are small pits, roughly aligned east/west, near the western edge of the APE. Each pit is irregular ovoid in shape and approximately 9 by 3 meters (30 by 12 feet). Based on comparison with a georeferenced historic map of Camp Logan (Rothrock 1918) the location of these pit features aligns with the indicated location of regimental pit latrines. During survey the pit features were filled with water. Therefore, shovel testing which might be able to confirm the features as latrine pits, was not carried out. Feature 3 is located approximately 21 meters 
REMOVED FROM PUBLIC COPY

Project area location on 1919 map of Camp Logan. 
REMOVED FROM PUBLIC COPY

Bayou Wilds - East survey results 
REMOVED FROM PUBLIC COPY

Site map for 41 HR6 14 
(70 feet) south of the pit features and consists of a long, shallow, ditch; approximately 165 meters (540 feet) long and 1 meter (3 feet) wide. The feature appears to be associated with several similar ditches previously recorded by Gray \& Pape (Quennoz 2018) to the west of the APE. These ditches are not shown on the Camp Logan Completion Report map (Rothrock 1918) but are visible on historic aerials as early as 1944 (Google, Inc. 2019). They appear to be an early attempt to help drain water away from the developed portions of Memorial Park to the north.

Feature 7 (Features 5 and 6 were later recategorized as Historic-Age Structures 1 and 2, see below) is a concrete signpost located near the entrance to Picnic Loop from Memorial Drive. The obelisk shaped post is labeled MEMORIAL DRIVE on one face and MEMORIAL LOOP DRIVE on the other (Figure 7-4). Similar concrete signposts can be seen throughout the City of Houston. These signposts date to a Depression Era program instituted by then mayor Oscar Holcombe in 1940 (Holcomb 1940). The entrance currently marked by Feature 7 was constructed between the late 1970s and early 1980s, which suggests the signpost was moved to its current location from the original entrance off Memorial Drive, 210 meters (690 feet) to the west (Google, Inc. 2019).

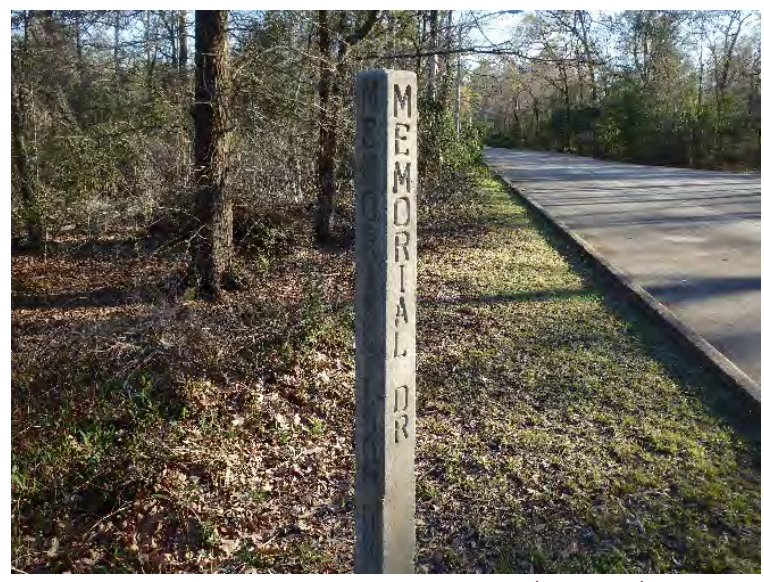

Figure 7-4. Feature 7. View is to the southeast.
Feature 8 is a surface scatter of historic age artifacts consisting primarily of glass (n $40+$ ) and ceramics ( $\mathrm{n} 20+$ ), covering 258 square meters $(2,777$ square feet). The Feature is concentrated on a wooded, level to gently sloping area overlooking a hiking trail and a steeply banked drainage at its western edge. The ceramic material consisted of whiteware with only a single piece of earthenware recorded, while the glass consisted almost entirely of clear bottle glass with the exception of one brown bottle base (Figure 7-5). Very small quantities of window glass, a piece of slag, and a single brick fragment were also noted. Several of the vessel glass pieces had legible bottle marks: an Owens Bottle Company mark (1919-1929), an Obear-Nestor Glass Company mark (1910s to 1930s), and a Tygart Valley Glass Company mark (1895-1959) (Whitten 2019). The Tygart Valley Glass Company base appears to match an example in the West Virginia Museum of American Glass (WVMAG), which is identified as a fruit jar, circa 1932 (WVMAG 2019). Several of whiteware pieces appear to have ornate embossed decorations and one had a scalloped rim. Only one of the white ware sherds had a backstamp, showing a fragmentary marking for the Homer Laughlin China Company. The date code was not preserved on the recovered sherd, but the stamp mostly closely resembles those in use between 1911 and 1919 (Gonzalez 2002). The earthenware rim sherd was likewise decorated.

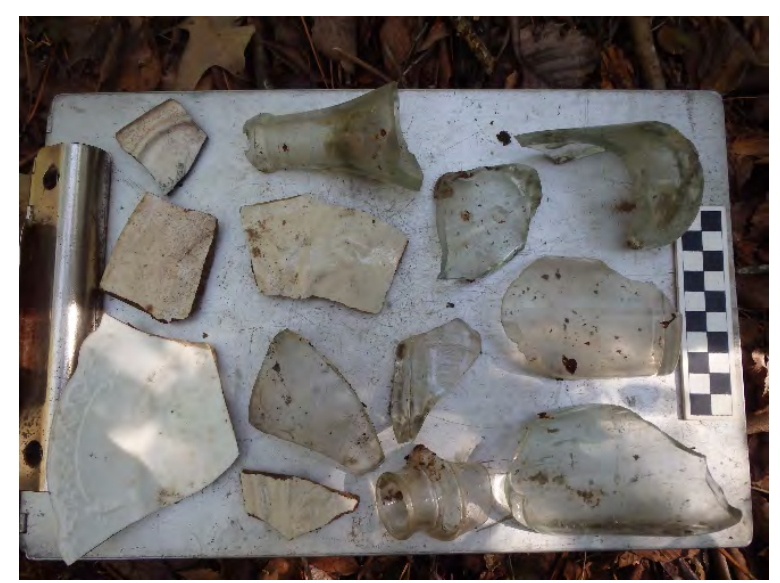

Figure 7-5. Selection of artifacts from Feature 8. 
Two excavated shovel tests were negative for cultural material. During the Camp Logan period, the area where Feature 8 is located sat immediately west of Fifth Street, which ran north/south, connecting Camp Logan to a bridge over Buffalo Bayou. However, no camp structure was indicated on historic maps in this area and the material does not appear to be consistent with the utilitarian ware that might be expected at a military camp. The bottle mark evidence suggests that the Feature postdates the closing of Camp Logan in 1919, perhaps the 1920s or 1930s. The preponderance of household wares and lack of deposition suggests the remains of a lightly used household dump location, perhaps associated with the period when the park caretaker lived on park grounds.

Feature 9 consists of a series of concrete foundations associated with the Camp Logan wastewater system (Figure 7-6, Figure 7-7). The remains are set into the slope of a ridge overlooking a flood basin. Prior to the mid2000's Buffalo Bayou made a western dog leg turn at this location which would have taken stream flow directly past the Feature. Today the main channel of the Bayou is located 92 meters (300 feet) to the east. The remains include a concrete footing wall near the top of the ridge and measuring 9.93 by 6.80 meters (32.6 by 22.3 feet). The exterior wall extends between 1.53 and 2.5 meters (5.0 and 8.2 feet) above the ground surface and a measurement taken at the interior northwest corner shows that the wall is at least 2.92 meters ( 9.6 feet) tall in total, extending down into the hillside. The walls are 32 centimeters thick with iron bolts for supporting a now missing superstructure placed every 180 to 190 centimeters (71 to 75 inches). A section of 70 -centimeter (27-inch) pipe, encased in a square concrete housing empties into the northeast corner of the footing wall. The concrete housing extends approximately 16 meters (52 feet) to the northwest. An outfall, 40 centimeters (15.7 inches) in diameter is cut into the southeast corner of the footing wall. The footing wall for a smaller structure sits slightly downslope approximately 6.3 meters (20.5 feet) from the south wall of the larger structure. The smaller structure measures approximately 7.57 by 5.60 meters (24.8 by 18.4 feet) and along the exterior is between 0.20 and 1.44 meters ( 0.7 and 4.7 feet) above the ground surface. However, breaks in three of the four walls make these measurements only approximates of the original structure's size. An inflow pipe enters in through the northern wall. The presence of a sill formed in the top of the footing wall suggests the former presence of superstructure. In addition to the breaks in the smaller of the footing walls, graffiti artists have tagged several walls of both structures. A hiking trail passes along the ridge top north of the Feature before dropping down along the west side into the flood basin below. A shovel test excavated immediately north of the Feature was negative for cultural resources, as was a test placed 15 meters (50 feet) to the west.

The Camp Logan Completion Report Map does not show a structure in this area (Rothrock 1918). However, an addendum to that report discusses additional work completed to the camp's sewer system. Work conducted between May and October of 1918 included the construction of a:

... accumulation tank twenty feet by thirty feet by thirteen feet with a capacity of forty thousand gallons. This tank is built of reinforced concrete covered with a wooden building. Near the top of this receiving tank is a fourteen inch overflow pipe which leads direct to Buffalo River, so that in case of emergency the sewage can be discharge temporarily into the stream. The sewage passes from the accumulation tank to the pump house... (Rothrock 1918). 
REMOVED FROM PUBLIC COPY

Feature 9 overview map. 
REMOVED FROM PUBLIC COPY

Feature 9 plan and profile drawings. 
The pumphouse then sent the water through pipe over Buffalo Bayou and eventually connecting to the City of Houston system. The larger of the Feature 9 footing walls appears to be the remains of the accumulation tank with the smaller footing representing the remains of the pump house. Based on the dimensions given in the completion report approximately 1 meter (3 feet) of sediment is currently located at base of the accumulation tank.

Feature 10 is a brick manhole located between the maintenance yard and Feature 9. A modern City of Houston manhole is located 1.8 meters ( 6 feet) to the north. The manhole shaft extends approximately 2.4 meters (8 feet) in depth, though sediment and debris at the base of the shaft prevents an accurate measurement of total depth. On one side of the shaft brick hand holds extend a few inches outward from the shaft wall (Figure 7-8). Opposite the brick hand holds, iron ladder rungs have been installed. An iron manhole cover is partially wedged in the opening but appears to not be original, being too small to properly fit the opening. Camp Logan brick manholes have been previously recorded in Memorial Park (Quennoz and Valenti 2017, Quennoz 2018), however those examples differ from Feature 10 in several ways. Those examples are bell shaped, seldom more than 1.8 meters (6 feet) deep, and the interior sealed with a cement coating. It is unclear if Feature 10 is associated with Camp Logan, or with later city and park infrastructure in the area.

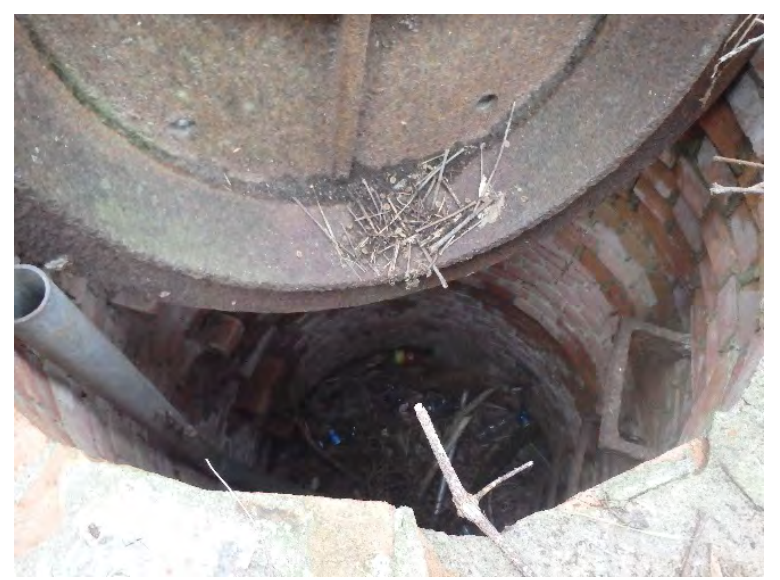

Figure 7-8. View of the interior of Feature 10.
Feature 11 is a low density, subsurface historic artifact concentration. The artifact concentration is located in a wooded area gently sloping to the south and west towards an erosional drainage. A hiking trail follows the edge of the slope delineating the southern and western edge of the feature. The northern and eastern extent of the feature was determined by shovel testing at roughly 10-meter (33-foot) intervals. A total of ten positive shovel tests produced mostly wire nails and nail fragments (n 12), though other items include whiteware fragments ( 11 , all from the same shovel test), an aqua colored glass stopper, horseshoe, two metal tent stakes, and several fragments of curled wire resembling bed springs. Based on color and style the glass stopper is from a Gartons HP Sauce bottle. A typical recorded stratigraphic profile was 16 centimeters $(6$ inches) of dark grayish brown (10YR4/2) mottled with brown (10YR5/2) sandy loam underlain by a light yellowish brown (10YR6/4) and brownish yellow (10YR6/6) sand to a depth of 40 centimeters ( 16 inches) below the surface. A light gray (10YR7/2) and brownish yellow (10YR6/8) sandy clay then extended to the base of the test at 50 centimeters (20 inches) below the surface. Cultural material was recovered at between 15 and 30 centimeters 16 and 12 inches) below the surface, typically at the base of the first stratigraphic unit.

During the Camp Logan period this area was located immediately west of Fifth Street. The Camp Logan Completion Report indicates a structure in this area; however the label is illegible (Rothrock 1918). Previous work (Quennoz 2018) has shown that clusters of iron nails as observed at Feature 11 are commonly associated with locations where wooden buildings such as dining halls were formerly located. Tent stakes, furniture springs, and horseshoes have been recorded previously at other locations with Memorial Park (Mangum et al 2017). These items should not be automatically assumed to be associated with Camp Logan. Horse and bridle trails were part of Memorial Park from its earliest inception (Suzanne Turner Associates 2015) and, 
although rare today, in the past groups often camped in Memorial Park. Gartons HP Sauce is an English fish sauce first made in 1903 and still common today. The colored glass stoppers were in use from around 1900 until approximately 1925 when the company moved to clear glass bottles with a screw on closure (History of Advertising Trust n.d.). This would seem to potentially, though not conclusively, date Feature 11 to the Camp Logan period. Interestingly sauce bottles, including HP Sauce, are a common artifact type recovered in archaeological excavations of WWI trenches in Europe. These bottles were often sent in care packages from Britain in order to improve the taste of the monotonous and often flavorless military fare (Robertshaw and Kenyon 2008).

Feature 12 is a United States Army Corps of Engineers Survey Mark. It is located in a maintained picnic area of the park and consists of the survey marker medallion set in concrete. The designation symbol indicates a vertical control mark, with an identifier as BB 78, and year of installation given as 1965 .

Feature 13 is a low-density surface scatter of late twentieth century artifacts over an approximately 1,740 square meter $(18,700$ square foot) area overlooking an erosional channel. Observed material included bottle glass, pull tab style aluminum cans, the rubber sole of a shoe, as well as fragments of brick, concrete and asphalt (Figure 7-9). Three shovel tests were all negative for cultural material. Historic aerial imagery shows that this area was cleared of vegetation and connected to the park maintenance yard by a road beginning in the 1960 's and continuing through at least the early 1970's. After this period both the clearing and access road were allowed to revegetate (Nationwide Environmental Title Research [NETR] 2019). Temporally diagnostic items such as paper label NEHI bottle and the presence of pull-tab cans suggest a post-1960's date for most if not all the material. It seems likely that this artifact concentration is representative of park maintenance activities taking places during this period.

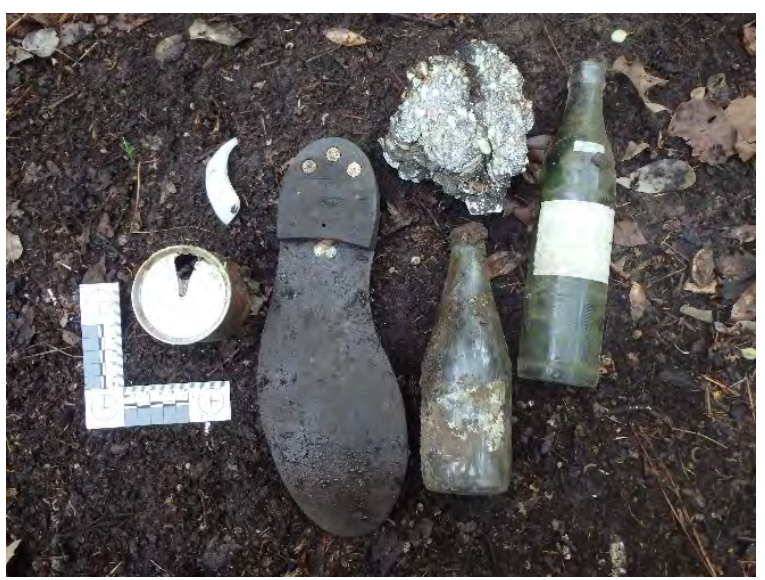

Figure 7-9. Selection of artifacts from Feature 13.

Temporary Site 1 is a low density lithic and prehistoric ceramic scatter recorded in the southwestern portion of the APE along the edge of a terrace overlooking Buffalo Bayou 47 meters (156 feet) to the southeast. Following the end of fieldwork activities, it was determined that Temporary Site 1 was in fact an eastward extension of the previously recorded $41 \mathrm{HR} 1217$ (Figure 7-10). Multiple hiking trails intersect at this location, impacting a portion of the site. After an initial positive shovel test, a further 10 radial shovel tests (three positive) were excavated at roughly 10-meter (33-foot) intervals. Radial shovel tests were placed in order to maximize testing of the level and intact portions of the terrace landform. Cultural material was recovered from between 14 and 40 centimeters (5 and 16 inches) below the surface. In general, the soil profile within the site produced three stratigraphic layers. A grayish brown (10YR5/2) sandy loam extended to a depth 15 centimeters (inches) below the surface and was underlain by a very pale brown (10YR7/3) sand to a depth of 40 centimeters (inches) below the surface. A very pale brown (10YR7/4) and brownish yellow (10YR6/8) sandy clay extended to the base of the test at 60 centimeters (inches) below the surface. A total of 10 chert flakes, 2 prehistoric ceramic fragments, and 1 point were recovered from the four positive shovel tests. The ceramic fragments were too small to definitively type but were sand tempered. The point was identified as a Perdiz 
REMOVED FROM PUBLIC COPY

Site map for 41HR1217 (Temporary Site 1). 
type made of gray chert (Figure 7-11). Perdiz points are typically dated A.D. 1200 to A.D. 1500 and are widespread across most of Texas during the Late Prehistoric period (Turner and Hester 1993). 41HR1217, is located on the same terrace landform, 35 meters (115 feet) west of Temporary Site 1 and was recorded by Gray \& Pape in 2018 as a prehistoric camp site consisting of a light scatter of ceramics and lithics (Quennoz 2018). Cultural material recorded at Temporary Site 1 is identical to that of $41 \mathrm{HR} 1217$ and occur in similar strata. As a result, Gray \& Pape believes Temporary Site 1 to be an eastward extension of $41 \mathrm{HR} 1217$. The 35-meter (115-foot) gap between the two artifact concentrations is likely the result of the trail construction in this area. The new site footprint is approximately 88 by 17 meters (288 by 57 feet).

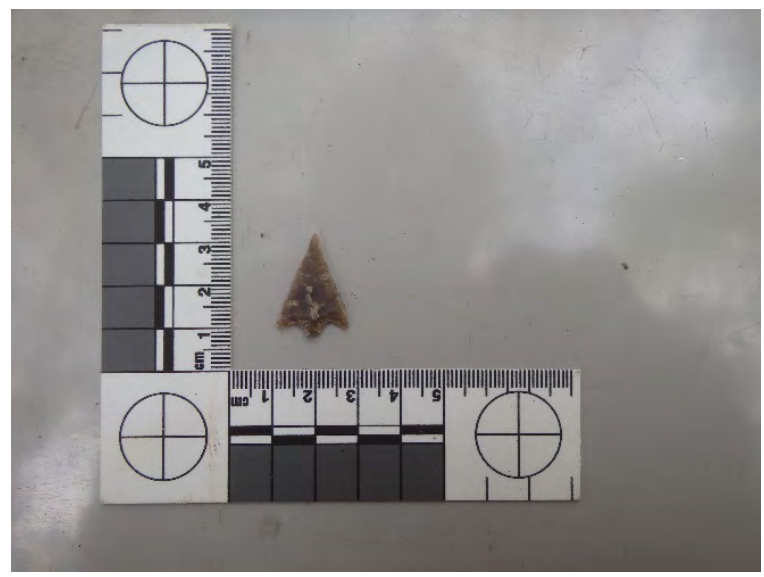

Figure 7-11. Perdiz point recorded at 41HR1217.

Site 41HR1226 (Temporary Site 2) is a low density lithic and prehistoric ceramic scatter recorded in the southern portion of the APE on top of a narrow east/west running ridge approximately 67 meters (221 feet) from Buffalo Bayou. A hiking trail and an incised erosional gully cut through the western portion of the site (Figure 7-12). After an initial positive shovel test, a further 10 radial shovel tests (two positive) were excavated at roughly 10-meter (33-foot) intervals. Radial shovel tests were placed in order to maximize testing of the level and intact portions of the ridge landform. The site footprint is approximately 36 by 6 meters $(118$ by 20 feet), with cultural material recovered between 35 to 65 centimeters ( 14 to 25 inches) below the surface. In general, the soil profile within the site produced two stratigraphic layers. A brown (10YR4/3) sandy loam extended to a depth of 35 centimeters (inches) below the surface. This was underlain by a light brownish gray (10YR6/2) sand that extended to the base of the shovel test at 110 centimeters (inches) below the surface. A total of six chert flakes and 1 prehistoric ceramic fragment were recovered from the three positive shovel tests. The ceramic fragment was too small to definitively type but was sand tempered.

41HR1227 (Temporary Site 3) is an extremely low-density lithic scatter recorded in the southern portion of the APE on top of a narrow northwest/southeast running ridge approximately 130 meters (427 feet) from Buffalo Bayou. Incised erosional gullies are located on either side of the ridge (Figure 7-13). After an initial positive shovel test, a further five radial shovel tests (one positive) were excavated at roughly 10-meter (33-foot) intervals. Radial shovel tests were placed in order to maximize testing of the level and intact portions of the ridge landform. Additional radial shovel tests were not excavated due to the steeply sloped sides of the landform. The site footprint is approximately 17 by 9 meters (56 by 30 feet), with cultural material recovered between 50 and 65 centimeters (20 and 26 inches) below the surface. In general, the soil profile within the site produced four stratigraphic layers. A very dark grayish brown (10YR3/2) and dark grayish brown (10YR4/2) loam was found to a depth of 10 centimeters (inches) below the surface. This was underlain by a brown (10YR5/3) and light yellowish brown (10YR6/4) sandy loam to 30 centimeters (inches) below the surface and a very pale brown (10YR7/3) sand to a depth of 70 centimeters (inches) below the surface. Between 70 and 80 centimeters (inches) below the surface, at the base of the test was a light gray (10YR7/2) and yellowish brown (10YR5/4) sandy clay. A total of one chert flake, one chert uniface, and one point of petrified wood were recovered from the two positive shovel tests. The 
REMOVED FROM PUBLIC COPY

Site map for 41HR1226 (Temporary Site 2) 
point was identified as a Yarbrough type which are dated to the Late Archaic period in Texas (Turner and Hester 1993).

$41 \mathrm{HR} 1228$ (Temporary Site 4) is a multicomponent site that was recorded in the southern portion of the APE on top of a narrow, mostly north/south running ridge approximately 67 meters (220 feet) from Buffalo Bayou. An incised erosional gully is located on the west side of the ridge. At its southernmost point the ridge begins a turn to the east, forming a terrace above Buffalo Bayou (Figure 7-14). After an initial positive shovel test, a further 11 radial shovel tests (four positive) were excavated at roughly 10-meter (33-foot) intervals. Radial shovel tests were placed in order to maximize testing of the level and intact portions of the ridge landform. The site footprint is approximately 48 by 14 meters $(157$ by 45 feet). The prehistoric component of the site consisted of two chert flakes recovered from two shovel tests at a depth of between 35 and 45 centimeters (14 and 18 inches) below the surface. A low to moderate density scatter of historic material was observed on the surface through the site. Cultural material consisted of primarily non diagnostic bottle glass and metal fragments, pull tabs from aluminum cans, bottle caps, crushed shell fragments, and small broken concrete pieces. Lager pieces of concrete were found in association with a broken concrete box. It resembles a concrete grill seen the photo of a Girl Scout cookout from the October 21, 1948 edition of the Southwestern Times (21 October 1948). Subsurface historic deposits were recorded in five shovel tests, beginning at the surface and extending to a depth of 35 centimeters (14 inches) below the surface. In general, the soil profile within the site produced two stratigraphic layers. To a depth of 35 centimeters (inches) below the surface was a very dark grayish brown (10YR3/2) and dark grayish brown (10YR4/2) sandy loam that was underlain by a very pale brown (10YR7/3) sand that extended to 110 centimeters (inches) below the surface at the base of the shovel test.

41 HR 1229 (Temporary Site 5) is a low density prehistoric lithic scatter that was recorded in the southern portion of the APE along a narrow northeast/southwest running ridge, sloping moderately towards Buffalo Bayou located approximately 50 meters (162 feet) to the south. The ridge is formed by two erosional gullies on either side (Figure 7-15). After an initial positive shovel test, a further six radial shovel tests (three positive) were excavated at roughly 10-meter (33-foot) intervals. Radial shovel tests were placed in order to maximize testing of the level and intact portions of the ridge landform. Additional radial shovel tests were not excavated due to the presence of the erosional gullies on either side of the landform. The site footprint is approximately 24 by 9 meters ( 80 by 30 feet), with prehistoric cultural material recovered between 40 and 50 centimeters (16 and 20 inches) below the surface. A total of four chert flakes were recovered from the three positive shovel tests. In general, the soil profile within the site produced four stratigraphic layers. A dark brown (10YR3/3) sandy loam was found to a depth of 25 centimeters (inches) below the surface and was underlain by a brown (10YR4/3) sandy loam to a depth of 50 centimeters (inches) below the surface. Between 50 and 70 centimeters (inches) was a dark grayish brown (10YR4/2) sandy loam. A light brownish gray (10YR6/2) and yellow (10YR7/8) sandy clay then continued to the base of the shovel test at 90 centimeters (inches) below the surface.

41HR1230 (Temporary Site 6) is a low density prehistoric lithic scatter that was recorded in the southern portion of the APE on top of a small, slightly raised landform approximately 52 meters (170 feet) from Buffalo Bayou. The landform is defined by an erosional gulley on its north and west sides and the steeply sloped banks leading towards Buffalo Bayou on the south side (Figure 7-16). 
REMOVED FROM PUBLIC COPY

Site map for 41HR1227 (Temporary Site 3). 
REMOVED FROM PUBLIC COPY

Site map for 41HR1228 (Temporary Site 4). 
REMOVED FROM PUBLIC COPY

Site map for 41HR1229 (Temporary Site 5). 
REMOVED FROM PUBLIC COPY

Site map for 41HR1230 (Temporary Site 6). 
A hiking trail and a utility corridor cut across the southern portion of the landform and the site. After an initial positive shovel test, a further 4 radial shovel tests (two positive) were excavated at roughly 10-meter (33-foot) intervals. Radial shovel tests were placed in order to maximize testing of the level and intact portions of the landform. The site footprint is approximately 17 by 12 meters (57 by 40 feet), with cultural material recovered between 27 and 35 centimeters ( 11 to 14 inches) below the surface. A total of four chert flakes were recorded from the three positive shovel tests. In general, the soil profile within the site produced three stratigraphic layers. A dark brown (7.5YR3/2) and brown (7.5YR4/2) sandy loam was encountered in the upper 16 centimeters (inches) and was underlain by a pale brown (10YR6/3) and very pale brown (10YR7/3) sandy to 27 centimeters (inches) below the surface. A very pale brown (10YR7/4) and yellow $(10 Y R 7 / 6)$ sandy clay then continued to the base of the shovel test at 50 centimeters (inches) below the surface.

Historic Age Structures 1 and 2 are very similar structures constructed of roughly formed concrete blocks sitting on poured concrete slabs (Figure 7-17). Historic Age Structure 1 sits above a large gulley 54 meters (176 feet) from the point where it empties into Buffalo Bayou. There is an unofficial, moderately trafficked hiking trail that passes nearby. Historic Age Structure 2 is located next to a smaller erosional gulley approximately 135 meters (444 feet) west of Buffalo Bayou. There are no nearby trails to Historic Age Structure 2. The style of construction is similar to that known as NPS Rustic which is best known from examples constructed within the National Parks by the Civilian Conservation Corps during the 1930s and 1940s. Developed in the early twentieth century in both federal and state parks, the style was designed to harmonize with the surrounding environment. Key characteristics include low and inconspicuous foundations, the use of native materials, simple or nonexistent decoration, low rooflines, and natural or warm colors to help blend into the background (Colorado Historical Society 2007).

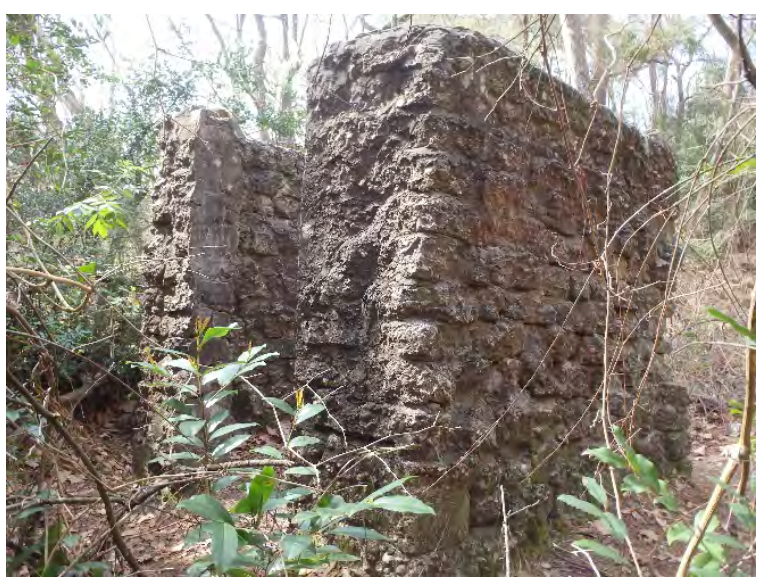

Figure 7-17. Historic Age Structure 1. View is to the southwest.

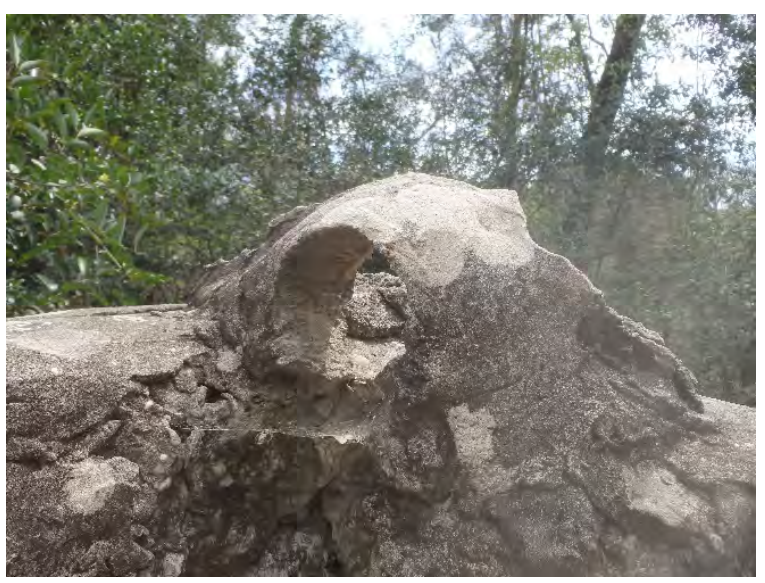

Figure 7-18. Detail of mortar roof bracket on Historic Age Structure 1.

The blocks appear to be made using cement mixed with large pebble aggregate to give the appearance of rough stone. The blocks are stacked in regular courses and joined by thick layers of mortar forming walls approximately 30 centimeters (12 inches) thick. Brackets formed from mortar appear to have secured beams that supported the roof, now completely missing (Figure 7-18). Detailed measurements for Historic Age Structure 1 show a footprint of 220 by 240 centimeters ( 87 by 95 inches) and a height of 205 centimeters (81 inches). The entranceway is 90 centimeters (35 inches wide) and a course of blocks divides the interior of the 
space. This row of blocks and a lip at the back of the structure appear to have supported a bench, now missing. Based on the style of construction the structures appear to be park shelters that date to sometime after the property became a city park in 1927. Although more research is required to determine an exact date of construction, it is notable that the NPS Rustic style is heavily associated with projects implemented by the Works Progress Administration and the Civilian Conservation Corps. The Works Progress Administration participated in the construction of the Memorial Park Golf Course which opened in 1936 (Emmott 1992). However, as yet, no documentation has been found to indicate if the Works Progress Administration or similar Depression Era program also conducted work in the larger Memorial Park.

Disarticulated and discarded pieces of concrete and/or brick were observed throughout the APE (Figure 7-2). These were most often along the slopes of erosional gullies at the edge of maintained park space, roads and maintenance areas (Figure 7-19). In the past this appears to have both been a matter of convivence in disposing of heavy concrete debris as well as a way to armor and protect eroding slopes near roads and maintained picnic areas. In most cases the concrete pieces were too fragmentary to identify, but in some cases, they were clearly the remains of concrete picnic tables and benches observed still in use in the park today.

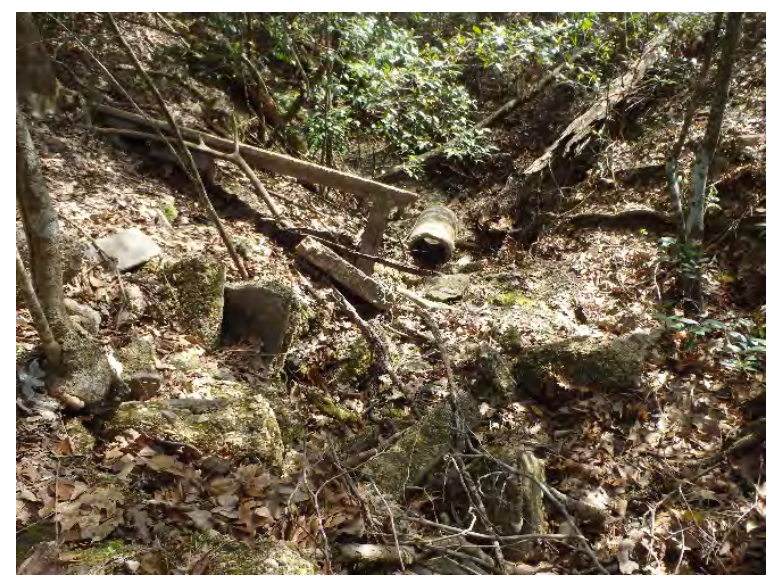

Figure 7-19. Typical example of concrete rubble deposited in erosional gully. View is to the east.
The most common picnic tables in the Picnic Loop are modern steel tube constructions, usually arranged on a concrete pad, with accompanying fire pit and grill. However, three older types, made of cast concrete, were also observed during survey. The most common type has curved legs (Type 1) while a less common style has straight legs (Type 2) (Figures 7-20 and 7-21). Another design consists of a ledged tabletop without associated benches (Type 3) (Figure 7-21). The age of the concrete picnic tables is not known. Suzanne Turner Associates (2015) identifies them with the WPA, but without explanation or citation to support that attribution.

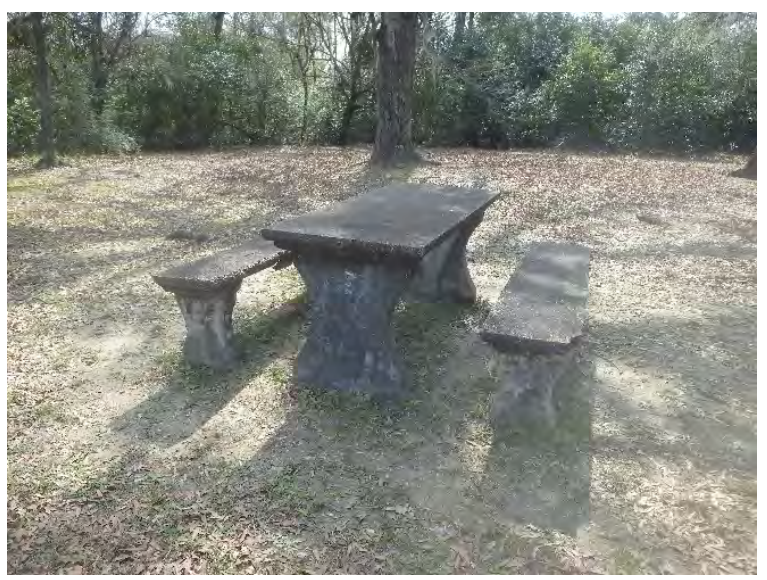

Figure 7-20. Type 1 picnic table. View is to the south.

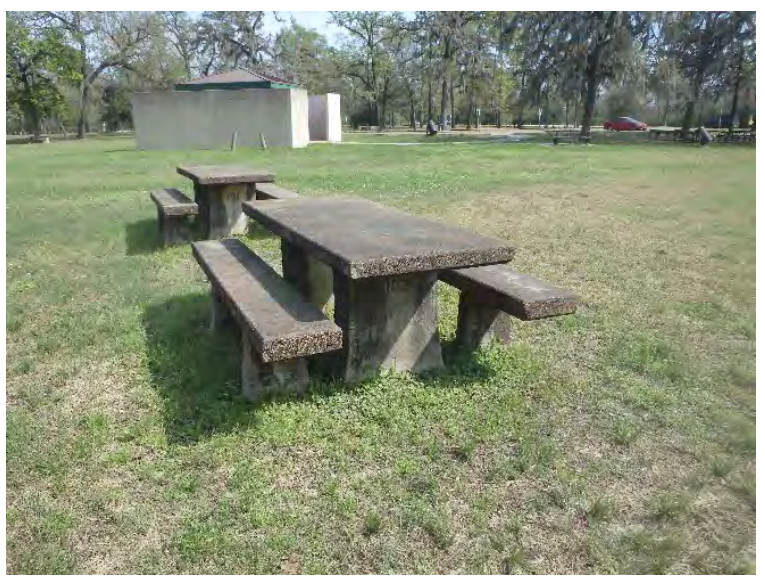

Figure 7-21. Type 2 picnic table. View is to the east. 


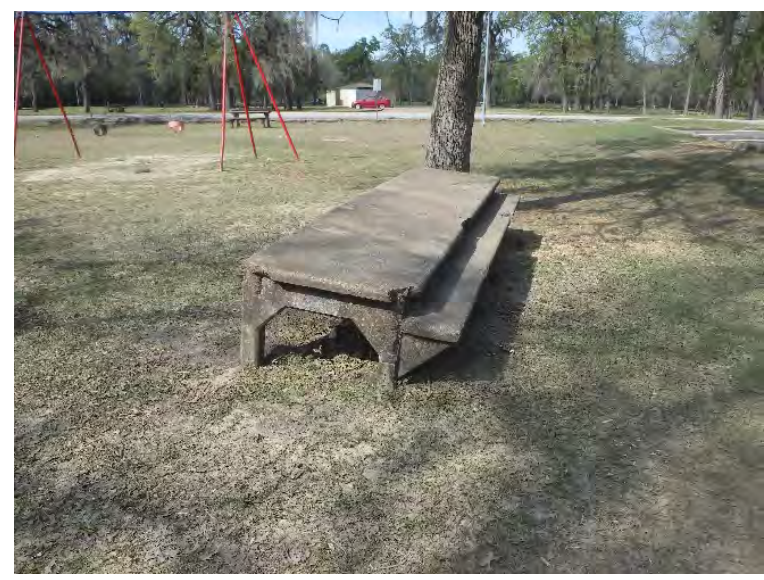

Figure 7-22. Type 3 picnic table. View is to the north.

\subsection{Conclusions and}

\section{Recommendations}

Based on the results of these surveys, Gray \& Pape would make the following recommendations. Fourteen features were identified associated with the previously recorded $41 \mathrm{HR} 614$ and the site boundaries were adjusted accordingly. During the operation of machinery in the area, protective fencing with a 5-meter (16-foot) buffer should be emplaced around Features 1, 2, 4, 7, 8, 9, 10, 11, and 13. Clearing within the buffer should be undertaken only by hand. Feature 3, a historic ditch feature, will not be impacted by planned activities, though caution should be taken when operating heavy machinery nearby, particularly in wet conditions when the soil is soft. Feature 12, a Corps of Engineers survey marker, is located in a maintained picnic area and will not be affected by MPC plans at this time.

As a result of survey, the boundary for $41 \mathrm{HR} 1217$ was extended and five new sites were recorded. $41 \mathrm{HR} 1217$ is a low density lithic and prehistoric ceramic scatter of Late Prehistoric age. $41 \mathrm{HR} 1226$ is a low density lithic and prehistoric ceramic scatter of unknown age. 41HR1227 is an extremely lowdensity lithic scatter of Late Archaic age. $41 \mathrm{HR} 1228$ is a multicomponent site with a very low-density scatter of prehistoric lithics with a moderate density scatter of twentieth century historic material on and just below the surface. 41 HR 1229 and 41HR1230 both consist of lowdensity lithic scatters of unknown age. For 41HR1217, 41HR1226, 41HR1227, 41HR1228, 41HR1229, and 41HR1230 Gray $\&$ Pape recommends that if heavy machinery is used in the area that protective fencing with a 5-meter (16-foot) buffer be emplaced around each site. Before any future work takes place within the site boundaries additional testing would be required for determining eligibility of any of the newly recorded sites identified during the survey.

Two Historic-Age Structures (HAS 1 and HAS 2) were recorded during survey. Both are in the National Park Rustic style and built of irregular concrete blocks. The exact purpose of these structures is unclear, but they appear to be associated with the early history of Memorial Park. During the operation of heavy machinery in the area of the structures it is recommended that protective fencing with a 5-meter (16-foot) buffer be emplaced. Clearing within the buffer should be undertaken only by hand.

Given the above precautions, Gray \& Pape believes that the discussed cultural resources within the APE will not be affected by MPC plans. If the MPC adjust plans in the future to include activities that will impact the identified features or that will include deep impacts within the APE, additional work would be required.

Findings were submitted to the THC for review and concurrence was received on September 24, 2019. 


\subsection{RESULTS OF NORTHWEST TRAILS - NORTH SURVEY}

The APE for the Northwest Trails - North project is located on the Houston Heights, TX 7.5minute USGS topographic quadrangle map (Figure 1-1). The 56-hectare (138-acre) APE is defined on its north side by property managed by the Houston Polo Club, on its east side by Southern Pacific Rail lines, to the south by Memorial Drive, and on its west by the private driveway of the Houston Polo Club. The majority of the APE consists of a mix of pine and oak woods with a heavily overgrown understory of briar and yaupon. Areas fronting Memorial Drive are regularly mowed and maintained as open parkland. A utility corridor runs the length of the eastern edge of the APE, while the western edge is located within the wooded median of Memorial Drive. Hiking and bridle trails are also located within the APE. At time of survey, the MPC planned to conduct standard park maintenance activities including mechanical clearing of the invasive understory, foliar application of herbicide, and new plantings.

\subsection{Previous Cultural Resource Work}

In 1989, MAC conducted a pedestrian survey of certain areas of Memorial Park, including 31.8 hectares (78.7 acres) that overlap with all but the northeastern and southern most portions of the current APE. MAC identified no historic features within the area, and five excavated shovel tests were negative for cultural material (Moore et al. 1989). In 2002, MAC conducted a second pedestrian survey of Memorial Park in order to determine relative archaeological potential within the park. The northern portion of the park where the APE is located, far removed from Buffalo Bayou and its tributaries, was considered to have a low potential for prehistoric sites (Moore and Sanchez 2002).

\subsection{Current Effort}

The survey of Northwest Trails - North consisted of pedestrian walkover survey and shovel testing (Figure 8-1). Pedestrian walkover survey focused on identifying the remains of above ground features as well as serving as reconnaissance for the shovel test survey which followed. The survey effort also made use of a georeferenced map included with the Camp Logan Completion Report (Rothrock 1918) in identifying and interpreting possible Camp Logan features. The historical record and maps indicate that the current area of study was not heavily utilized during the Camp Logan period. The camp's Remount Depot, where most of the horses were housed, was located north of the APE, in the area between Interstate 10 and Katy Road. All other Camp Logan related facilities were on the eastern side of the railroad tracks.

Four Historic Age Structures (1-4) were recorded during the course of the survey (Figure 8-2). These consist of nearly identical footbridges that are part of the park hiking and bridle trail system. The spandrels for these bridges are constructed from irregular blocks joined by cement mortar. The blocks form an arch at either end of an approximately 3-meter (10-foot) long, 1.2-meter (4-foot) diameter, concrete culvert. Packed earth was then used to cover the culvert and form the bridge deck. Steel tube piping, set in concrete, was used to form a railing on each side. Currently no firm date of construction is available on these footbridges. However, historical aerial imagery shows that the trail system with which they are associated, first appears between 1944 and 1953 (Google, Inc. 2019). Discarded indeterminate concrete rubble was recorded on the surface in two locations. 
REMOVED FROM PUBLIC COPY

Northwest Trails - North field survey results. 


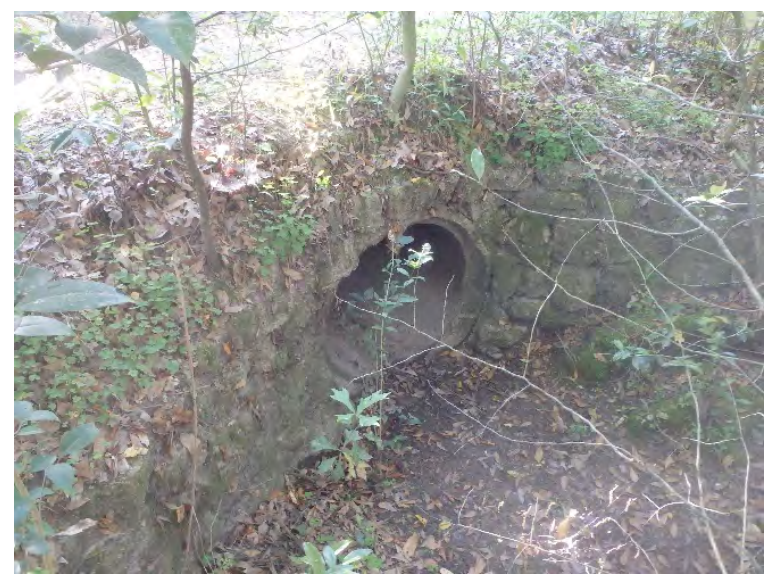

Figure 8-2. Historic Age Structure 4. View is to the southeast.

A total of 205 shovel tests were attempted across the APE; six were left unexcavated due to inundation and 22 were left unexcavated due to significant surface disturbance. All but one of the excavated shovel tests were negative for cultural resources (Figure 8-1). Inundated areas were concentrated in the northeastern portions of the APE, which was marshy in character and showed signs of regular inundation. This area was also observed to contain a number of ditches designed to collect and concentrate surface water. Based on their condition, and by referencing historical aerial images, these appear to be modern constructions. Surface disturbances were also recorded along the eastern edge of the APE, where buried fiberoptic lines, high power electric lines, and railroad grade maintenance areas are present. A second area of disturbance was located within the wooded and grassy median of Memorial Drive, along the project's western edge. Shovel Test N04 was the only shovel test positive for cultural material. A broken thermometer or pressure gauge was recorded at a depth of 20 centimeters ( 8 inches) below the surface. Eight delineation shovel tests excavated at 10-meter (33-foot) intervals were all negative for cultural material and the item is being considered a historical isolate.

Soils encountered during the course of the survey were largely consistent across the APE as well as with the mapped soils for the area.
Typical soil profiles are seen in Shovel Tests G04 and $\bigcirc 07$ (Figure 8-3). In G04, the upper 10 centimeters (4 inches) consisted of a brown (10YR 4/3) silty loam underlain by a grayish brown (1OYR 5/2) silty clay to a depth 45 centimeters (18 inches) below the surface. Between 45 and 65 centimeters (18 and 26 inches) was a grayish brown (10YR 5/2) silty clay with yellowish brown (10YR 5/8) mottling. In 007 , the upper 20 centimeters (8 inches) consisted of a grayish brown (10YR 5/2) clay loam. This was underlain by a light brownish gray (10YR 6/2) clay with yellowish brown (10YR 5/8) mottles to a depth of 70 centimeters (28 inches) below the surface. The most notable deviation in soil profile was observed in northeastern portion of the APE where saturated clays were often encountered at the surface. An example would be Shovel Test G17 where a dark gray (10YR 4/1) saturated silty clay with yellowish brown (10YR 5/8) mottles was observed from the surface to a depth of 40 centimeters (16 inches) below the surface, at which point the shovel test began to fill with water. Tests excavated along the western edges of the APE, within the wooded median of Memorial Drive; and the eastern edge of the APE where the utility corridor is located, were the most likely to display disturbed or fill soils.

\subsection{Conclusions and Recommendations}

During the course of survey, Gray \& Pape identified four historic structures. All four were footbridges that are part of the existing Memorial Park trail system. Of 205 attempted shovel tests, only one was positive for cultural material, an unknown historic-age gauge. Delineation tests were all negative for cultural material and the find is therefore considered a Historic Isolate and no site number will be assigned. Based on the results of these surveys, Gray \& Pape would make the following recommendations. During planed project activities, protective fencing with a 5-meter (16foot) buffer should be emplaced around Historic Structures 1-4. Clearing within this buffer should be undertaken only by hand. 


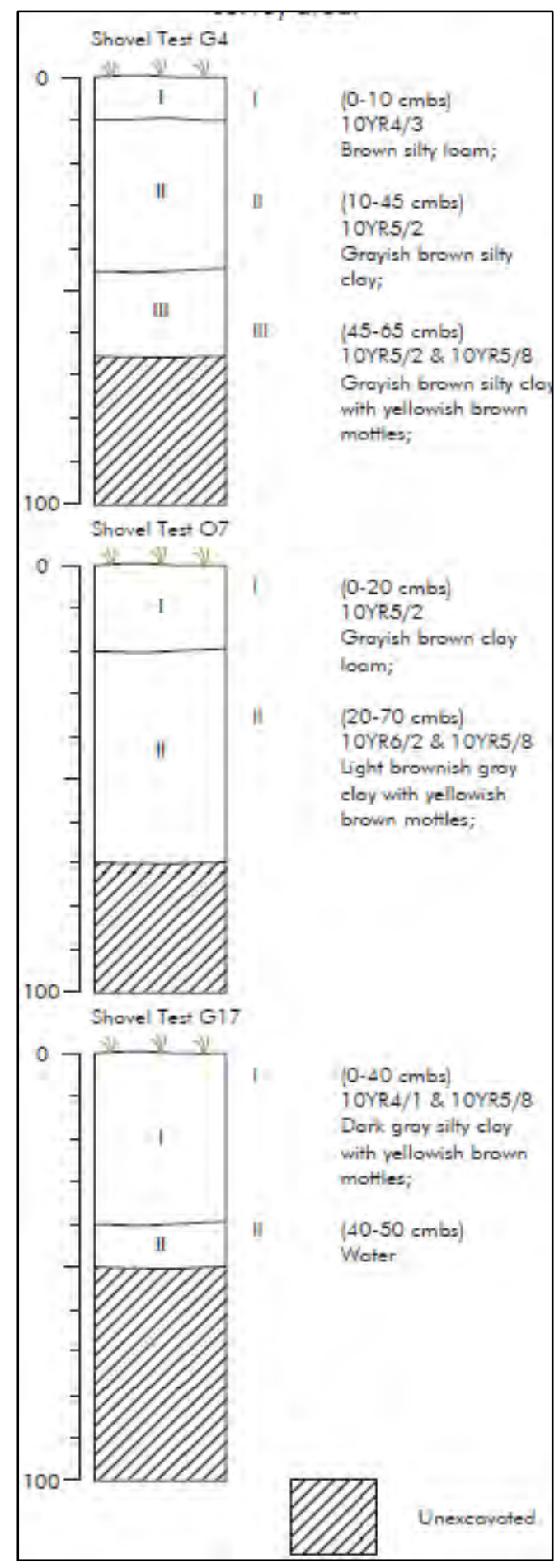

Figure 8-3. Soil profiles for Northwest Trails North.
Given the above precautions, Gray \& Pape believes that the discussed cultural resources within the APE will not be affected by MPC plans. If the MPC adjust plans in the future to include activities that will impact the previously identified features or that will include deep impacts within the APE, additional work would be required.

Findings were submitted to the THC for review and concurrence was received on June 11, 2019. 


\subsection{ADDITIONAL WORK FOR 2018-2019}

In addition to survey work, Gray \& Pape worked with the MPC in identifying, recording, and making recommendations in regard to cultural material encountered during the course of construction (Unanticipated Finds), as well as assisting the MPC in its coordination efforts with the THC on planned projects for which additional survey work was not warranted based on past efforts.

\subsection{Unanticipated Finds}

A total of nine cultural resources were encountered during project activities. When park personnel or their contractors encountered a previously unrecorded cultural resource a previously established Unanticipated Discoveries Plan was followed by all parties (Appendix C). All work was halted in the vicinity of the find and the MPC contacted Gray \& Pape to perform a site visit. During that visit a Gray \& Pape archaeologist would document the new find, photograph, and record its location using a hand-held GPS unit. Location data would then be included in a master GIS database of all cultural material located in Memorial Park. A table of cultural resources included in this database is in included in Appendix B.

Within the Eastern Glades project area seven new archaeological features were encountered and recorded (Figure 9-1). Five were manholes, one was a grease trap, and one was a section of vitrified clay sewer pipe. The Eastern Glades project area was surveyed by MAC in 2016 (Mangum et al. 2017) and by Gray \& Pape in 2017 (Quennoz and Valenti 2017). After concurrence of findings and recommendations was received from the THC, the MPC moved forward with Eastern Glades project plans that included vegetative clearing, road realignment, the construction of a detention pond and drainage system, new parking lots and hardscapes, restrooms and comfort stations, as well as all associated utilities. It was during the implementation of these plans that the previously unidentified features were encountered.

Features 1, 3, 4, and 5 were manholes that appeared to be consistent with examples recorded elsewhere in the park and associated with Camp Logan. Typically, Camp Logan manholes are constructed of brick and mortar. The diameter at the ground surface is 105 centimeters (41 inches) and has an opening of 62 centimeters (24 inches). In examples not completely filled with sediment it has been observed that the interiors are bell shaped and coated with mortar to make them watertight. In several examples pipe openings are seen entering into manhole and at least one example had the remains of ladder rungs. Of the Camp Logan manholes thus far recorded, only one retained its original manhole cover (Quennoz and Valenti 2017, 2018, Quennoz 2018).

Features 3, 4, and 5 were found completely filled with sediment and submerged in standing water (Figure 9-2). Feature 1 had its opening secured with a sheet of bolted iron. This appears to have been a replacement for the missing manhole cover. Although an examination of the interior of these features was not possible, their observable characteristics were consistent with other Camp Logan examples. Their location when located on a georeferenced copy of the Camp Logan completion report map (Rothrock 1919) shows them aligning with structures associated with a brigade headquarters and officers mess halls, further confirming a Camp Logan association. Project plans are not expected to impact Features 3 and 4, and temporary protective fencing was emplaced around them during construction activities to avoid potential damage. Feature 5 is located next to a planned picnic area. After consultation with Bill Martin (personal communication 2019) at the THC, it was determined that after documentation that the feature would not otherwise be impacted and could be filled and buried. 
REMOVED FROM PUBLIC COPY

Unanticipated finds locations. 


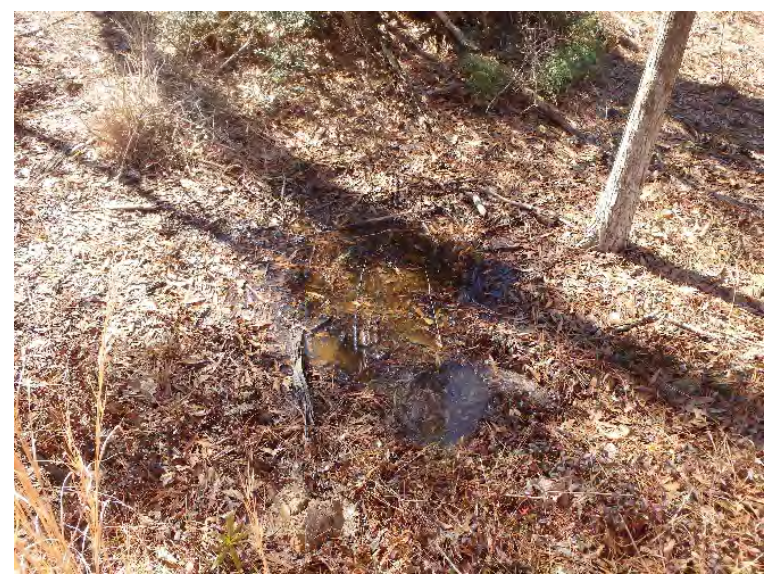

Figure 9-2. Feature 5, a partially submerged manhole. View is to the southeast.

Feature 6 has a different design than the other identified manholes (Figure 9-3). Rather than bell shaped it is straight walled and deeper, with an approximate depth of 2.5 meters (8.0 feet). It also lacks a full cement coating observed in the Camp Logan manholes. The location of Feature 6 likewise does not align with any structures or infrastructure identified on the Camp Logan completion report map (Rothrock 1918). For these reasons Feature 6 is believed to postdate Camp Logan and is perhaps associated with construction of the Golf Course, located northwest of the Feature. Project plans are not expected to impact Feature 6, and temporary protective fencing was emplaced around it during construction activities to avoid potential damage.

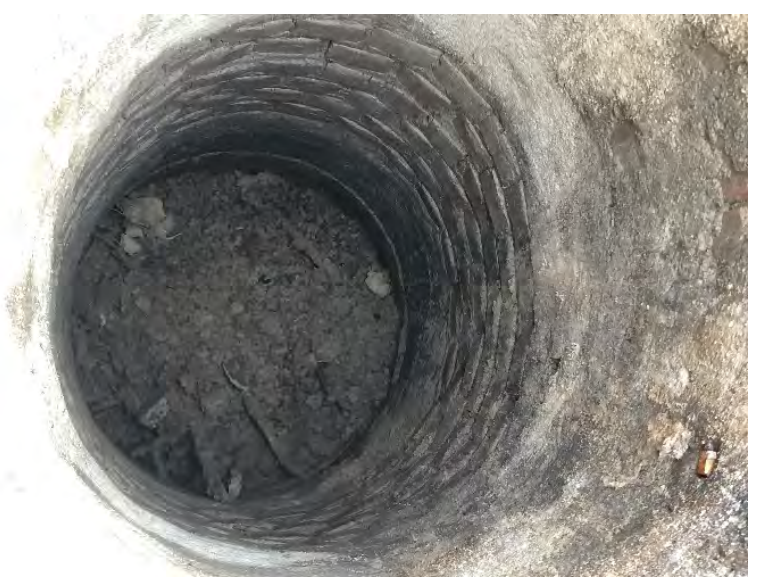

Figure 9-3. A view of the interior of Feature 6.
Feature 2 has been identified as a Camp Logan era grease trap (Figure 9-4). Three other examples have been identified in other areas of the park and are of similar size and construction (Quennoz 2018). Feature 2 is a rectangular concrete foundation divided in half by a wall creating two interior squares. The feature is approximately 4.25 by 1.92 meters $(14.0$ by 6.3 feet) and with walls 19.5 centimeters (7.7 inches) thick. Project plans are not expected to impact Feature 2, and temporary protective fencing was emplaced around it during construction activities to avoid potential damage.

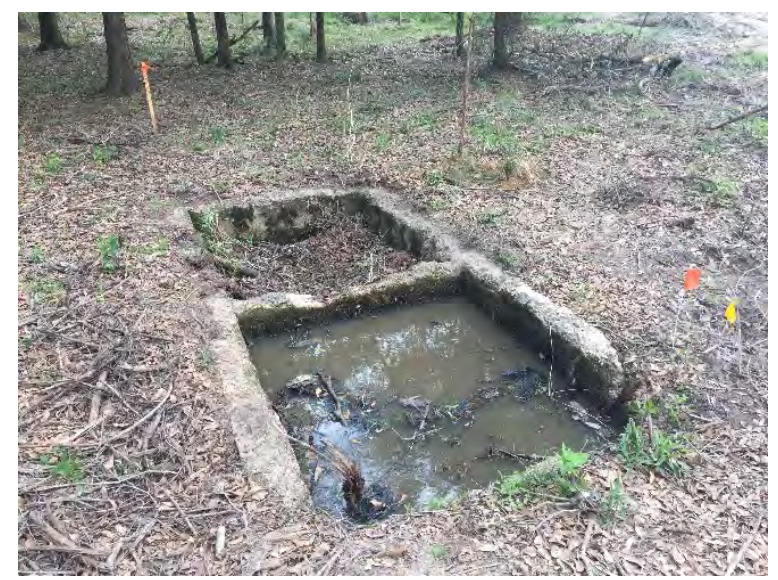

Figure 9-4. Overview of Feature 2. View is to the north.

Feature 7 is an approximately 1 -meter (3-foot) long exposed section of 15 -centimeter (6-inch) diameter vitrified clay pipe, 1.2 meters (4.0 feet) below the surface (Figure 9-5). The pipe was oriented slightly north of east/west and continues an unknown distance in both directions. Feature 7 is located in an area that was the Camp Logan post office, and several other buildings (the camp hostess house and several Red Cross structures) were located further to the north. A Camp Logan association is possible but not definitive. Project plans were adjusted so that there were no further impacts in the area, and after recording the section of pipe was reburied. 


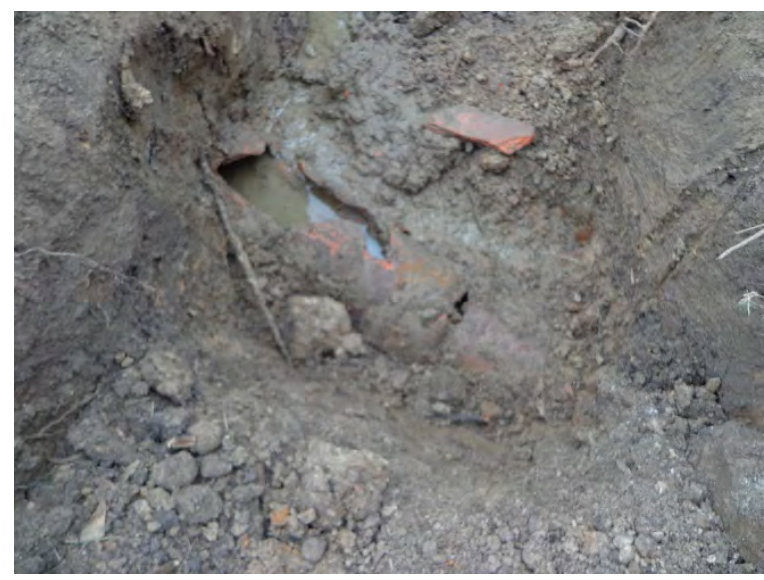

Figure 9-5. Overview of Feature 9. View is to the north.

Within the Land Bridge project area, one new archaeological feature was encountered and recorded (Figure 9-1). Feature 12 is believed to be another example of a Camp Logan manhole. The most notable characteristic of this Feature is that because an erosional gulley has formed around it, most of the exterior has been exposed (Figure 9-6). The bell shape, typical of the Camp Logan manholes is clearly visible and the exterior is coated in mortar, similar to the interior of previously examined examples. Similar to Feature 1 in the Eastern Glades area, this example has a piece of sheet iron bolted over it's opening in place of the original manhole cover.

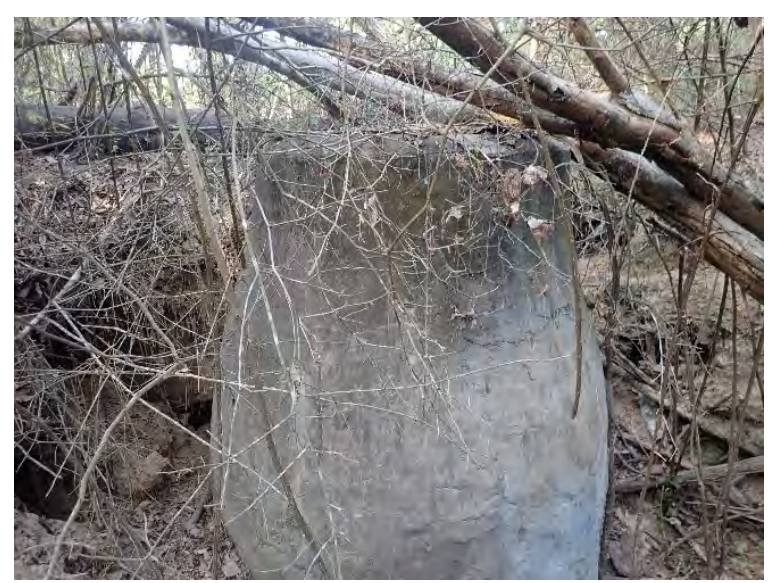

Figure 9-6. Feature 12 in the Land Bridge area. View is to the southeast.
Feature 6 was identified and recorded in the Sports Complex project area. The feature was a typical example of a Camp Logan manhole with a bell shape and mortar coating (Figure 9-7). This particular example was approximately 30 centimeters ( 1 foot) below the modern grade ad located in a heavily modified part of the park that is now a traffic circle. Project plans call for a grade reduction in this area that would impact the feature. As a result, after coordination with the $\mathrm{THC}$, the upper section of the feature was removed and the remained reburied in situ.

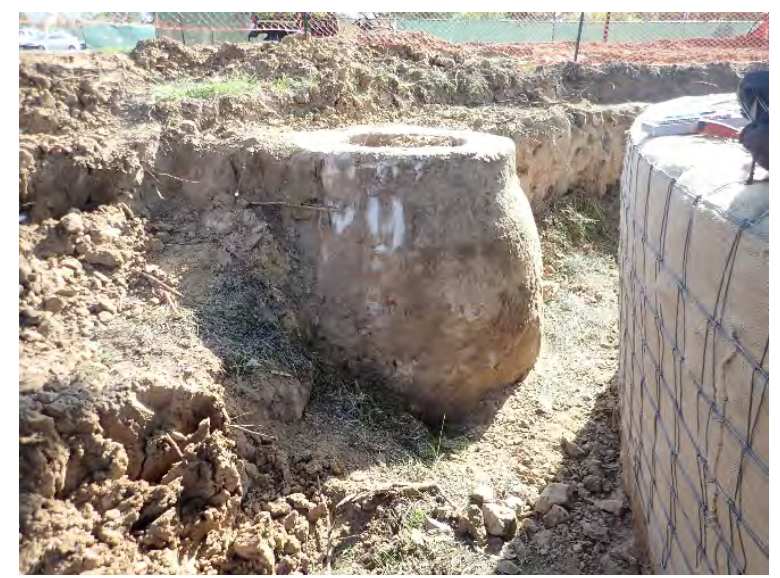

Figure 9-7. Overview of Feature 6 in the Sports Complex area. View is to the east.

\subsection{Coordination Efforts}

Gray \& Pape also coordinated with the THC on two occasions in regard to MPC projects for which no fieldwork was required. These letters are included in Appendix D at the end of the report. 


\subsection{CONCLUSION AND RECOMMENDATIONS}

On behalf of the City of Houston and the MPC, Gray \& Pape conducted intensive pedestrian surveys of five areas totaling 146.5 hectares (362.0 acres) of Memorial Park, City of Houston, Harris County, Texas (Table 1-1). Fieldwork was carried out between April 1, 2018 and March 31, 2019, under Texas Antiquities Annual Permit Number 8465. The goals of the intensive pedestrian surveys were to assist the MPC in identifying the presence of cultural resources as they are defined by Section 106 of the NHPA of 1966, as amended (36 CFR 800), and provide management recommendations for identified resources. Survey methods, site identification and delineation, and reporting adhere to standards established by the Archeology Division of the THC, the Council of Texas Archeologists, and the NHPA of 1966. At this time, the MPC plans to conduct standard park maintenance activities including low impact mechanical clearing of the invasive understory, spraying, and new plantings in each of the areas surveyed.

Gray \& Pape focused particular attention on the State Antiquities Landmark-designated (\#8200003264) Camp Logan archaeological site (41HR614) that encompasses large portions of Memorial Park. As a result of survey findings, the boundary for $41 \mathrm{HR} 614$ has been expanded to include the entirety of the former Camp Logan footprint as preserved within the boundaries of Memorial Park. The boundary of the previously recorded prehistoric Site $41 \mathrm{HR} 1217$ was also extended. Work carried out during the permit period also identified four new prehistoric sites (41HR1226, 41HR1227, 41HR1229, 41HR1230) and one new multicomponent site (41HR1228).

The 12.4-hectare (30.6-acre) Sports Complex survey resulted in the identification of five historic features considered part of 41HR614: the partial remains of a Camp Logan era road; segments of two Camp Logan era ditches; a Camp Logan concrete grease trap; and a concrete signpost from the 1940s. Gray \& Pape recommends that the grease trap and signpost be avoided by MPC planned activities. The remaining features will not be impacted by current planned MPC activities. Based on the results of this survey, and with these protective measures in place, Gray \& Pape recommends that the no further cultural resources work be required in the remaining portions of the Sports Complex project area and that the project be cleared to proceed as currently planned.

The 76-hectare (189-acre) Bayou Wilds - East survey resulted in the identification of four new prehistoric sites (41HR1226, 41HR1227, 41HR1229, 41HR1230) and one new multicomponent site (41HR1228). The boundaries of the prehistoric Site 41HR1217 and the historic Site 41HR614 were extended. A total of 14 new features were identified as associated with $41 \mathrm{HR} 614$, as well as two historic-age structures. Gray \& Pape recommends avoidance of the identified sites, features, and historic-age structures. Based on the results of this survey, and with these protective measures in place, Gray \& Pape recommends no further cultural resources work be required in the remaining portion of the Bayou Wilds - East project area and that the project be cleared to proceed as planned.

The 56-hectare (138-acre) Northwest Trails North survey resulted in the identification of four historic-age structures, nearly identical footbridges constructed of irregular blocks and mortar that are part of the park's active trail network, as well as a historical isolate. Based on the results of this survey, and with these protective measures in place, Gray \& Pape recommends that the no further cultural resources work be required in the remaining portions of the Northwest Trails - North project area and that the project be cleared to proceed as currently planned. 
As part of the Unanticipated Finds Plan developed by Gray \& Pape and the MPC, Gray \& Pape archaeologists identified and recorded nine cultural features (seven manholes, one grease trap, and one segment of vitrified clay pipe) uncovered by activities undertaken by the MPC and their contractors. In each case ongoing work in the area of the newly encountered feature was halted until the feature was fully documented by a Gray \& Pape archaeologist, and potential impacts were coordinated between Gray \& Pape, the MPC, and the THC.

Gray \& Pape also coordinated with the THC on two occasions in relation to MPC projects for which no fieldwork was required. 


\subsection{REFERENCES CITED}

Abbott, James $T$.

2001 Houston Area Geoarcheology; A Framework for Archeological Investigation, Interpretation, and Cultural Resource Management in the Houston Highway District. Texas Department of Transportation, Environmental Affairs Division.

Aten, Lawrence $\mathrm{E}$.

1983 Indians of the Upper Texas Coast. Academic Press, New York.

1984 Woodland Cultures on the Texas Coast. In Perspective on Gulf Coast History, edited by Dave D. Davis, pp. 72-93. Ripley P. Bullen Monographs in Anthropology and History, No. 5. Florida State Museum, University Press of Florida, Gainesville.

Aulbach, Louis F., Linda C. Gorski, and Robbie Morin 2014 Camp Logan: Houston, Texas 1917-1918. Louis F. Aulbach, Houston, Texas.

Barnes, V.E.

1992 Geologic Atlas of Texas, Houston Sheet, revised. Bureau of Economic Geology, The University of Texas at Austin.

Barrett, Jason W. and Richard A. Weinstein

2013 Data-Recovery Investigations and Public Outreach at the Dimond Knoll Site (41HR796). Texas Archeology: The Newsletter of the Texas Archeological Society 57(3):14-15.

Biesaart, Lynne A., Wayne R. Robertson, and Lisa Springs

1985 Prehistoric Archaeological Sites in Texas: A Statistical Overview. Office of the State Archaeological Report 28. Texas Historical Commission, Austin.

Black, Marshall

1987 Letter to Joan Few. Dated May 14, 1987.

Chowdhury, Ali H. and Mike J. Turco

2006 Geology of the Gulf Coast Aquifer, Texas in Aquifers of the Gulf Coast of Texas. Robert E. Mace, Sarah C. Davidson, Edward S. Angle, and William F. Mullican, III, Editors. Texas Water Development Board, Austin.

Colorado Historical Society

2007 Rustic Style Architecture in the Colorado State Register of Historic Properties. Colorado Historical Society, Denver.

Culberson, Linda C.

1993 Arrowheads and Spear Points in the Prehistoric Southeast: A Guide to Understanding Cultural Artifacts. University Press of Mississippi, Jackson. 
Davis, Gene P.

1996 An Archaeological Survey of Proposed Wastewater Treatment and Collection System Improvements for the Forest Cove Municipal Utility District, Harris County, Texas. Texas Water Development Board.

Emmott, Sarah H.

1992 Memorial Park: A Priceless Legacy. Herring Press, Houston.

Few, Joan

1988 Archeological Site Form for 41HR617. Texas Archeological Sites Atlas. https://atlas.thc.state.tx.us/. Accessed May 24, 2019.

Fleisher, Jeffrey

2015 Final Report on Archaeological Research at Camp Logan (44HR614), a World War I Training Camp in Memorial Park, Houston, Texas. Rice University Archaeological Field Techniques Class (Anthropology 362), Houston.

Google, Inc.

2018 Aerial photographs of from 1944, 1954, 1978, 1989, 1995, 2002, 2004, 2006, 2008, 2009, 2010, and 2011, 2017. Google Earth. Accessed May 24, 2019.

Gonzalez, Mark

2002 An Overview of Homer Laughlin Dinnerware. Schiffer Publishing, Atglen.

Gregory, H.F.

1986 The Southern Caddo: An Anthology. Garland Publishing: New York.

Haynes, Robert V.

2010 "Houston Riot of 1917," Handbook of Texas Online (http://www.tshaonline.org/handbook/online/articles/jch04), Accessed February 10, 2018.

Hendrickson, Corporal Paul B.

1918 Map of "Camp Logan-Houston, Tex."

Henson, Margaret

2010 "Harris County, TX." The Handbook of Texas Online http://www.tsha.utexas.edu/handbook/online/articles/HH/hch7.html. Accessed February 10, 2018.

History of Advertising Trust

n.d. A Brief History of HP Sauce and its Use of Glassware.

Holcombe, Oscar

1940 Oscar Holcombe Radio Address, October 30, 1940. The Houston Metropolitan Research Center. http://digital.houstonlibrary.net/oral-history/oscarholcombe_OH388.php. Accessed August 12, 2018. 
Holloway, Vance T.

1997 Paleoindian Geoarchaeology of the Southern High Plains. The University of Texas Press, Austin.

Houston Post

1919 "Six Y.M.C.A. Buildings at Logan Sold Saturday". March 16, 1919. Houston, Texas.

1919 "Camp Logan Mess Halls: Only a Few Left - Be Quick". July 30, 1919. Houston, Texas.

Houston Public Works

2019 GIMS - Public Utility Map. www.gims.houstontx.gov/PublicUtilityMap/. Accessed May 6, 2019.

Hudson, Charles

1976 The Southeastern Indians. The University of Tennessee Press, Nashville.

Hwang, Tiffany

2012 "US Army Field Jacket Development in Response to Material Shortages and the Exigencies of World War II". Momentum. Vol. 1, Issue 1.

La Vere, David

1998 The Caddo Chiefdoms: Caddo Economics and Politics, 700-1835. The University of Nebraska Press, Lincoln.

John A. Logan Museum

2014 John A. Logan Museum. http://www.loganmuseum.org. Accessed February 10, 2018.

Mangum, Douglas $G$.

2012 An Archeological Investigation of the Proposed Memorial Park Running Center, Harris

County, Texas. Moore Archeological Consulting, Inc.

Mangum, Douglas G., Eleanor Stoddart, and Anastasia Gilmer

2017 An Archeological Investigation of the Proposed Eastern Glades, Phase I Project, Harris County, Texas. Moore Archeological Consulting, Inc., Houston.

McLeod, Todd, C. Wesley Mattox, and Hannah Curry-Shearouse

2017 Archaeological Survey of Proposed Houston Arboretum \& Nature Center Improvements, Harris County, Texas. SWCA Environmental Consultants, Houston.

\section{Memorial Park Conservancy}

2018 "Memorial Park Heritage Historical Timeline" (http://www.memorialparkconservancy.org/heritage/historical-timeline.html) Accessed February $10,2018$.

Molineu, Douglas, Joseph Sanchez, Curtis Dusek, Mark Lozano, Mark Wagner, Carol Bookout, and Janet Wagner

2010 Archery Range, Memorial Park, City of Houston Parks Department, Harris County, Texas. J. K. Wagner \& Company, Inc. 
Moore, Roger G., William E. Moore, and David S. Pettus

1989 An Archeological Survey of Nine Land Units Within Memorial Park in Houston (Harris County), Texas. SLA Studiland.

Moore, Roger G. and Joseph M. Sanchez

2002 An Archeological Assessment of Portions of the City of Houston Memorial Park, Harris County, Texas. Moore Archeological Consulting, Inc.

Munsell Soil Color Chart (Munsell)

2005 Revised Edition. Macbeth Division of Kollmorgan Instruments Corporation.

Nationwide Environmental Title Research, LLC (NETR) Online

2019 Houston Heights, TX 7.5 Minute Quadrangle Topographic Map, 1:24,000 (1915, 1922, 1932, 1946, 1957, 1970, 1983, 1998, 2013). Aerial images (1953, 1957, 1962, 1964, 1966, 1973, 1981, 1995, 2002, 2004, 2009, 2010, 2012, 2014). URL: http://www.historicaerials.com/. Accessed May 24, 2019.

Newcomb, W.W. Jr.

1961 The Indians of Texas From Prehistoric to Modern Times. The University of Texas Press, Austin.

Patterson, Leland W.

1995 The Archeology of Southeast Texas. Bulletin of the Texas Archeological Society 66:239264.

1996 Southeast Texas Archeology. Report No. 12, Houston Archeological Society.

Quennoz, Michael

2018 2017-2018 Annual Report of Work Carried Out at Memorial Park, City of Houston, Harris County, Texas. Gray \& Pape.

Quennoz, Michael and Vincent Valenti

2017 Cultural Resources Survey for the Proposed Memorial Park Eastern Glades Phase 2 Development Project, Memorial Park, City of Houston, Harris County, Texas. Draft Report, Gray \& Pape, Inc. Houston.

2018 A Cultural Resources Survey for the Proposed Memorial Groves Development Project, Memorial Park, Harris County, Texas. Gray \& Pape, Inc. Houston.

Robertshaw, Andrew and David Kenyon

2008 Digging the Trenches: The Archaeology of the Western Front. Pen \& Sword Military, South Yorkshire.

Rothrock, Captain W.P.

1918 Completion Report of Camp Logan Houston, Texas. War Department, Office of the Quartermaster, Fort Worth. 
Shafer, Harry J.

1975 Comments on the Woodland Cultures of Texas. Bulletin of the Texas Archeological Society 46:249-254.

Sjoberg, A.A.

1951 The Bidai Indians of Southeastern Texas. Southwestern Journal of Anthropology 7(4).

Soil Survey Staff, Natural Resources Conservation Service, United States Department of Agriculture (SSS NRCS USDA)

2019 Web Soil Survey. Available URL: http://websoilsurvey.nrcs.usda.gov/app/WebSoilSurvey.aspx . Accessed May 24, 2019.

Southwestern Times

1948 "Girl Scout leaders of the Southwestern section". October 21, 1948. Houston, Texas.

Story, Dee Ann

1990 Cultural History of the Native Americans. In The Archeology and Bioarcheology of the Gulf Coastal Plain 1: 163-366. 2 vols. Research Series No. 38. Fayetteville, Arkansas Archeological Survey.

Suzanne Turner Associates

2015 Cultural Landscape Review, Appendix to the Memorial Park Master Plan. Suzanne Turner Associates, Baton Rouge.

SWCA Envrionmental Consultatns

2017 Memorial Park Biological Assessment. https://issuu.com/memorialparkhouston/docs/memorial_park_initial_biological_as. Accessed June 17, 2019.

Texas State Antiquities Code

1977 Natural Resources Code, Title 9 - Heritage, Chapter 191, Subchapter A, Section 191.001.

Thomas, Robert

2003 "World War I Training Camps," Dictionary of American History (http://encyclopedia.com/doc/1 G2-3401804604.html), Accessed February 10, 2018.

Turner, E.S. and T.R. Hester 1993 A Field Guide to Stone Artifacts of Texas Indians, 2nd Edition. Texas Monthly Field Guide Series. Gulf Publishing Co., Houston.

United States Geological Survey (USGS)

1998 Houston Heights, Texas Quadrangle (7.5 minute). USGS.

Van Siclen, D.C. 
1991 Surficial Geology of the Houston Area: An Offlapping Series of Pleistocene (\& Pliocene?) highest Sea Level Fluviodeltaic Sequences. Transactions of the Gulf Coast Association of Geological Societies, 41:651-666.

West Virginia Museum of American Glass

2019 Tygart Valley Glass Company fruit jar. Catalog Number 2012.262.1. Online Collection of the Museum of American Glass. https://magwv.pastperfectonline.com/weboject/DC251CF2-4B09-4347-986A085085788407. Accessed May 7, 2019.

Wheeler, Frankie F.

1976 Soil Survey of Harris County, Texas. United States Department of Agriculture, Soil Conservation Service, Washington D.C.

Whitten, David

2019 Glass Bottle Marks. www.glassbottlemarks.com. Accessed May 7, 2019. 


\title{
APPENDIX A HISTORIC CAMP LOGAN MAPS
}

\author{
Removed from public copy.
}




\section{APPENDIX B}

\section{TABLE OF RECORDED FEATURES}

Removed from public copy. 


\section{APPENDIX C \\ UNANTIPATED FINDS PLAN}

Removed from public copy. 


\section{APPENDIX D COORDINATION LETTERS}

Removed from public copy. 